\title{
Reproductive biology, morphology, and morphometry of ovaries and oviducts of Trachemys scripta elegans in Brazilian Cerrado ${ }^{1}$
}

\author{
Adriana Gradela ${ }^{2 *}$ (D), Isabelle Caroline Pires ${ }^{2}$, Maria Helena T. Matos², \\ Fábio Mathias Corrêa ${ }^{3}$, Marcelo D. Faria ${ }^{2}$, Josilane S. Silva² ${ }^{2}$ Laio Ramon C. Torres ${ }^{2}$ \\ and Liliane Milanelo ${ }^{4}$
}

\begin{abstract}
Gradela A., Pires I.C., Matos M.H.T., Corrêa F.M., Faria M.D., Silva J.S., Torres L.R.C. \& Milanelo L. 2020. Reproductive biology, morphology, and morphometry of ovaries and oviducts of Trachemys scripta elegans in Brazilian Cerrado. Pesquisa Veterinária Brasileira 40(2):141-154. Laboratório de Anatomia dos Animais Domésticos e Silvestres, Colegiado de Medicina Veterinária, Fundação Universidade Federal do Vale do São Francisco, Rodovia 407 Km 12, Lote 543, Projeto Nilo Coelho C1, Petrolina, PE 56300-000, Brazil. E-mail: agradela@hotmail.com

Although Trachemys scripta elegans is an exotic species popular as a pet in Brazil, studies on reproductive biology and capacity are non-existent in the Brazilian Cerrado. This study analyzed ovarian and oviduct characteristics and the egg production capacity of T. scripta elegans grown in this biome. The findings will associate with the size of the specimens and the sexual maturity, aiming at comparisons with native and exotic populations, as well as interspecific and contributing to the understanding of its impact on the invaded ecosystems and the establishment of eradication programs. Thus, 39 females had evaluated the body biometry and the morphology and morphometry of the ovaries and oviducts. G2 (N=20): with Class I ( $>5-10 \mathrm{~mm})$ follicles, with Class I and Class II ( $>10$-fold) follicles, $25 \mathrm{~mm})$ and G3 (N=9) with Class I, Class II and Class III ( $>25 \mathrm{~mm}$ ) follicles. Analysis of variance, Scott-Knott's test, and Pearson's correlation analysis showed that there was no significant difference between the groups in body biometry; in the mean gonadosomatic index and gonadal morphometry, only the width of the oviducts in the right antimer and the mass and width in the left antimer were higher in G3, the only one that presented eggs. There was positive and harmonic development between body mass, carapace, and plastron, and gonadal growth occurred concomitantly with body growth, indicating a higher reproductive potential and a positive relationship between the size of the litter and the female litter. The gonadosomatic index proved to be an excellent reproductive indicator, and the ovarian evaluation was a better indicator of sexual maturity than the maximum carapace length. Ovaries were irregular structures, without delimitation between the cortical and medullary regions and filled with vitelogenic follicles of different diameters, atresic follicles, and corpora lutea, which reflected the ovarian complexity of the species and the presence of follicular hierarchy. In the scarce stroma, two germinative beds were observed per ovary and the presence of gaps very close to the follicles and associated with the blood vessels. Analysis of gonadal tissue revealed three types of oocytes according to cytoplasmic characteristics: homogeneous, vesicular or vesicular in the cortex with apparent granules. Oviducts were functional and separated, joining only in the final portion to form the cloaca and subdivided into infundibulum, tuba, isthmus, uterus, and vagina. The structure of the uterine tube was composed of serosa, muscular and mucous, which was full of glands. The presence of eggs in the oviducts indicated
\end{abstract}

\footnotetext{
${ }^{1}$ Received on July 2, 2019.

Accepted for publication on August 16, 2019.

${ }^{2}$ Universidade Federal do Vale do São Francisco (Univasf), Rodovia 407 Km 12, Lote 543, Projeto Nilo Coelho C1, Petrolina, PE 56300-000, Brazil. *Corresponding author: agradela@hotmail.com
}

\footnotetext{
${ }^{3}$ Department of Statistics, Rhodes University, New Arts Block, Artillery Road, Grahamstown, Bhisho 6139, South Africa.

${ }^{4}$ Centro de Recuperação de Animais Selvagens (CRAS), Parque Ecológico do Tietê (PET), Departamento de Águas e Energia Elétrica (DAEE), Rua Guirá-Acangatara 70, Engenheiro Goulart, Guarulhos, SP 03719-000, Brazil.
} 
that the specimens can reproduce in the Brazilian Cerrado. This study provides necessary and relevant information on the reproductive biology and capacity of T. scripta elegans in the Brazilian Cerrado and can contribute to the understanding of its impact on the invaded ecosystems and the establishment of eradication programs. The extraction of females with capacity can reduce the annual reproductive yield of the species and decrease its effect on local biodiversity.

INDEX TERMS: Reproduction, biology, morphology, morphometry, ovaries, oviducts, Trachemys scripta elegans, Brazilian Cerrado, Testudines, uterine tube, ovary, follicles, corpus luteum. RESUMO.- [Biologia reprodutiva, morfologia e morfometriade
ovários e ovidutos de Trachemys scripta elegans no
Cerrado Brasileiro.] Embora Trachemys scripta elegans seja uma espécie exótica popular como animal de estimação no Brasil, estudos sobre biologia e capacidade reprodutivas são inexistentes no Cerrado brasileiro. Este estudo analisou características ovarianas e do oviduto e a capacidade de produção de ovos em T. scripta elegans criadas neste bioma, correlacionando estes achados ao tamanho dos espécimes e a maturidade sexual, visando comparações com populações nativas e exóticas, bem como interespecíficas e contribuir para a compreensão de seu impacto nos ecossistemas invadidos e com o estabelecimento de programas de erradicação. Assim, 39 fêmeas tiveram avaliadas a biometria corporal e a morfologia e morfometria dos ovários e ovidutos. De acordo com o tamanho dos folículos ovarianos as fêmeas foram separadas em G1 ( $\mathrm{N}=10)$ : com folículos Classe I $(>5-10 \mathrm{~mm})$, G2 (N=20): com folículos Classe I e Classe II (>10-25 mm) e G3 (N= 9) com folículos Classe I, Classe II e Classe III (>25 mm). À análise de variância, teste de Scott-Knott e à análise de correlação de Pearson verificou-se que não houve diferença significativa entre os grupos na biometria corporal; no índice gonadossomático médio e na morfometria gonadal, apenas a largura dos ovidutos no antímero direito e a massa e a largura no antímero esquerdo foram maiores no G3, o único que apresentou ovos. Houve desenvolvimento positivo e harmônico entre massa corporal, carapaça e plastrão e o crescimento gonadal ocorreu concomitante ao crescimento corporal, indicando maior potencial reprodutivo e relação positiva entre o tamanho da ninhada de ovos e o da fêmea. 0 índice gonadossomático mostrou-se um bom indicador reprodutivo e a avaliação ovariana um melhor indicador da maturidade sexual que o comprimento máximo da carapaça. Ovários foram estruturas irregulares, sem delimitação entre a região cortical e medular e repletos de folículos vitelogênicos de diferentes diâmetros, folículos atrésicos e corpos lúteos, que refletiram a complexidade ovariana da espécie e a presença de hierarquia folicular. No estroma escasso foram observados dois leitos germinativos por ovário e a presença de lacunas muito próximas aos folículos e associadas aos vasos sanguíneos. A análise do tecido gonadal revelou três tipos de oócitos de acordo com as características do citoplasma: homogêneo, vesicular ou vesicular no córtex com grânulos aparentes. Ovidutos eram funcionais e separados, unindo-se apenas na porção final para formar a cloaca e subdividiam-se em infundíbulo, tuba uterina, istmo, útero e vagina. A estrutura da tuba uterina era constituída de serosa, muscular e mucosa, a qual era repleta de glândulas. A presença de ovos nos ovidutos indicou que os espécimes podem se reproduzir no cerrado brasileiro. Este estudo fornece informações básicas e relevantes da biologia e capacidade reprodutivas de T. scripta elegans no Cerrado brasileiro e pode contribuir com a compreensão de seu impacto nos ecossistemas invadidos e com o estabelecimento de programas de erradicação, uma vez que a extração de fêmeas com capacidade reprodutiva pode contribuir com a diminuição do rendimento reprodutivo anual da espécie e diminuir seu efeito sobre a biodiversidade local.

TERMOS DE INDEXAÇÃO: Biologia, reprodução, morfologia, morfometriade, ovários, ovidutos, Trachemys scripta elegans, Cerrado Brasileiro, Testudines, tuba uterina, ovário, folículos, corpo lúteo.

\section{INTRODUCTION}

The introduction of exotic species is one of the reasons for the extinction of half of the other species of turtles (TCF 2002), representing a severe threat to the maintenance of biodiversity (Strayer et al. 2006, Ricciardi 2007, Ficetola et al. 2009). The impact of the species on the native biodiversity has been observed with Trachemys scripta elegans (Wied, 1839), an underwater turtle from North America (Ernst \& Barbour 1989), very popular as pet worldwide (Telecky 2001, Crescente et al. 2014). Its popularity is due to small size, simple breeding requirements, and affordable price. However, when adult, they may acquire a considerable size (up to $30 \mathrm{~cm}$ carapace length) and can survive for up to 50 years in captivity (Teillac-Deschamps et al. 2008), which may result in their abandonment by breeders (Lever 2003, Martinez-Silvestre et al. 2003, Teillac-Deschamps et al. 2008). As it presents earlier maturity and higher fecundity than most other species when establishing themselves in new habitats, they compete with native chelonians (Perez-Santigosa et al., 2008) and threaten local biodiversity (Fonseca 2001, Buhlmann et al. 2009). In some areas where they are introduced, T. scripta elegans are unable to reproduce due to low temperatures or limited precipitation (Bringsøe 2001, Ficetola et al. 2009), with few reports of naturalized populations (Pleguezuelos 2002, Lever 2003, Cadi et al. 2004, Ramsay et al. 2007, Kikillus et al. 2010).

In Quelonians the studies about morphology of the ovary and uterine tubes (O'Malley 2005, Machado Junior et al. 2006, Hildebrand \& Goslow 2006, Cabral et al. 2011, Silva et al. 2011, Chaves et al. 2012, Firmiano et al. 2012), particularly the biometrics of the somatometric and intern. The available studies, mostly, focus on the description of breeding behavior and nesting (Firmiano et al. 2012) and the few existing ones emphasize the morphofunctional aspects of gonads in females (Ferreira \& Dolder 2003, Ceriani \& Wyneken 2008, Peixoto et al. 2012, Souza et al. 2014). However, the study of reproductive organs and ovarian follicular development and egg production are essential to understanding the adaptive and evolutionary aspects involved in their differentiation, as well as the establishment of strategies for species management, 
conservation and eradication (Newman et al. 2003, Pessoa et al. 2008, Pérez-Bermúdez et al. 2012).

In marine turtles, morphophysiological alterations of the reproductive tract are observed as a function of age and the reproductive and non-reproductive season. A pair of ovaries composes the reproductive system; a pair of oviducts; suspensory ligaments (mesovary, mesosalpinx, and mesotubaric) and clitoris (Wyneken 2001). The oviduct begins in the region adjacent to the ovary and extends to the sewer, presenting five regions: infundibulum, tubal uterine or magno, isthmus, uterus, and vagina (gross muscle region) (Girling 2002). Ovulated follicles form the luteal bodies that, after ceasing the progesterone production, become albicans, similarly to domestic mammals (Hafez \& Hafez 2004). Larger corpora lutea are usually younger than the smaller ones and indicative of ovulation (Wyneken 2001).

This study aimed to describe the reproductive biology of T. scripta elegans bred in the Brazilian Cerrado through gonadal and oviduct analysis, and of the presence of eggs in the oviducts, correlating these findings with the size of the specimens and sexual maturity, and adaptation to the biome, aiming at comparisons with native, exotic and populations, as well as interspecific populations. In this form we hope, we shall contribute to the understanding of the impact of this species on the invaded ecosystems and the establishment of eradication programs.

\section{MATERIALS AND METHODS}

Animals. Adult females of Trachemys scripta elegans (Wied, 1839, Testudines order) ( $\mathrm{N}=39$ ) received by the "Centro de Triagem de Animais Silvestres" (CETAS) of the "Parque Ecológico do Tietê", Guarulhos/SP $\left(23^{\circ} 29^{\prime} 23.15^{\prime \prime} S\right.$ and $\left.46^{\circ} 31^{\prime} 10.90^{\prime \prime} \mathrm{W}\right)$ were euthanized using the combination of xylazine hydrochloride $\left(40 \mathrm{mg} \mathrm{kg}^{-1}\right)$ and ketamine ( $60 \mathrm{mg} \mathrm{kg}^{-1}$ ) administered intramuscularly and perfusion of propofol $\left(50 \mathrm{mg} \mathrm{kg}^{-1}\right)$ in the vertebral canal through the atlantooccipital joint. Afterward, they were frozen and transported (Licenses IBAMA no. 136/2011 and no. 048/2012) in Styrofoam boxes with dry ice to the Laboratory of Anatomy of Domestic and Wild Animals (LAADS) of the "Universidade Federal do Vale do São Francisco" (Univasf) in Petrolina, state of Pernambuco $\left(9^{\circ} 23^{\prime} 34^{\prime \prime} \mathrm{S}\right.$ and $40^{\circ} 30^{\prime} 28^{\prime \prime}$ W) for study. SISBIO/IBAMA (protocol \# 38601-1) and the Ethics Committee on Animal Use (CEUA) of Univasf (protocol number 0002/160412; 0003/160412; 0004/160412) approved this study.

Body biometry. After body thawing, the body mass (BM) was evaluated using the millimeter precision analytical balance (Bioprecisa ${ }^{\circledR}$, Labmais Ltda., Curitiba/PR, Brazil), the maximum length (CL) and width (CW) of the carapace; the maximum length (PL) and width $(\mathrm{PW})$ of the plastron using a tape measure (in $\mathrm{cm}$ ) according to Malvasio et al. (1999). Post-cloacal length (PoCL in cm) was analyzed with the aid of a millimeter precision caliper (Mitotoyo ${ }^{\circledR}$ ).

Biometrics of ovaries, ovarian follicles and oviducts. After incision of the bridge with hammer and chisel and removal of the plastron the general disposition of the internal organs was observed and the intestines, liver, and stomach were removed with the help of thin tipped scissors for visualization of the ovaries and oviducts. Ovaries and oviducts were removed from the coelomic cavity. The right (R) and left (L) ovaries had the mass (ROM and LOM, in grams) evaluated using KERN analytical balance and the length (ROL and LOL, cm), width (ROW e LOW) and follicle diameter (mm) with the aid of a millimetric precision pachymeter. The follicles were classified into three types according to the diameter: Class I ( $>5-10 \mathrm{~mm})$; Class II ( $>10-25 \mathrm{~mm})$ and Class III $(>25 \mathrm{~mm})$ and quantified. Follicles of 0 to $4 \mathrm{~mm}$ were excluded from the count because they were generally pre-vitellogenic and provided little useful information on ovarian activity (Kuchling \& Bradshaw 1993). Based on the follicular type present in the ovaries, the females were divided into three groups: $\mathrm{G} 1(\mathrm{~N}=10)$ : Class I follicles; $\mathrm{G} 2(\mathrm{~N}=20)$ : Class I and Class II follicles; and G3 (N=9): Class I, Class II and Class III follicles. The presence of atresic follicles and corpora luteawas also recorded, but not quantified.

The right (R) and left (L) oviducts had the mass (ROvM and LOvM, in grams) evaluated using KERN analytical balance and the length (ROvL and LOvL, in cm), width (ROvW e LOvW, in $\mathrm{cm}$ ) and thickness (ROvT and LOvT, in $\mathrm{cm}$ ) with the aid of a millimetric precision pachymeter.

For the quantitative analysis of the reproductive activity, the gonadosomatic index (GSI) was calculated using the formula: GSI $=\mathrm{TMg} / \mathrm{BM} \times 100$, where $\mathrm{TMg}$ is the total mass of the gonads and BM is the body mass of each female. The right oviduct (ROv) and left oviduct (LOv) had their mass (M, in grams); length ( $\mathrm{L}$, in $\mathrm{cm}$ ), width (W, in $\mathrm{cm}$ ) and thickness ( $\mathrm{T}$, in $\mathrm{cm}$ ) evaluated as described above and the number of eggs estimated.

Sexual maturity evaluation. Sexual maturity was established following the criteria of Limpus \& Limpus (2003). Females were considered pre-pubescent immatures when they had ovaries without expanded stroma, vitellogenic follicles, corpus luteum or albicans, and white oviducts. They were considered immature pubescent when they had ovaries with small expansion, developing follicles, but without the presence of corpus luteum or albicans. Mature females displayed expanded stroma, vascularized and vitellogenic follicles $(0.5-3.0 \mathrm{~mm}$ in diameter), the presence of corpus luteum and albicans, distended and sinuous oviducts with or without the presence of eggs.

Morphology of reproductive organs and ovarian follicles. Fragments of the right ovary and oviduct were fixed by buffered immersion in $10 \%$ buffered formalin for 24 hours, dehydrated in increasing alcohol $(70 \%, 80 \%, 90 \%$, and $100 \%)$, clarified in xylol and embedded in paraffin. The five $\mu \mathrm{m}$ sections were stained with hematoxylin-eosin (HE) and evaluated under light microscopy for morphological description. The oviduct fragment was collected from the largest region, which corresponds to the uterine tube between the area between the infundibulum and the isthmus region.

Evaluation of the oocyte development stage. The oocyte development stage was established according to the methodology proposed by Rosa (2005). The initial stage (Ho) was characterized by homogeneity of the cytoplasm, which, although enlarged, did not display any synthesis of reserve material.The second stage (Vc) by the presence of vacuoles in the cytoplasm, which had no uniform distribution or evident granules. The third stage (Vp) by the presence of vacuoles and apparent granules in the cytoplasm cortex, and the fourth stage (Gr) by the presence of granular oocytes and increased cytoplasm.

Statistical analysis. Confidence intervals were constructed for the sample mean $(\alpha=0.05)$, and the variables were submitted to analysis of variance and Scott-Knott's test afterward. The observed variables were also submitted to Pearson correlation analysis using the model residues. For the variables related to the total number of eggs produced per group, correspondence analysis was performed to evaluate the association between oocyte size and quantity produced. All analyzes were performed using software R. 


\section{RESULTS}

Analysis of body, ovarian, oviductal and follicular biometrics

The variables that presented a significant difference were the mass, width, and thickness of the right oviduct and the width and thickness of the left tube (Table 1).

Three size classes were defined, each with an interval of five centimeters, according to the CL (Fig.1). In all three groups, the majority of females presented from 17.00 to $21.00 \mathrm{~cm}$ of $\mathrm{CL}$, with the lowest female $\mathrm{G} 1=14.00 \mathrm{~cm}, \mathrm{G} 2=12.40 \mathrm{~cm}$, and $\mathrm{G} 3=16.70 \mathrm{~cm}$. Thelargest female had, respectively in each group, $23.80 \mathrm{~cm}, 22.80 \mathrm{~cm}$, and $22.90 \mathrm{~cm}$.

Correlation analysis indicated a significant correlation between BM and CL, CW, PL, PW and LOL; between CL and CW, PL, PW and PoCL; between CW and PL; between PL and PW and LOL; between ROM and ROL; between LOM and LOL and ROvW; between ROvM and LOvM; between ROvW and ROvT, LOvW and LOvT; between ROvT and LOvW and LOvT and between LOvW and LOvT (Fig.2) in all groups studied.

G2 had a higher total number of follicles $(\mathrm{P}<0.05)$ than G1 and G3 in the right antimer and G1 in the left and greater total numbers $(\mathrm{P}<0.05)$ than the $\mathrm{G} 1$ and $\mathrm{G} 3$ groups (Table 2$)$.

Correspondence analysis indicated that there is an association between the class of follicles and the size of the follicles produced, independent of the ovary side. In other words, Class I follicles were associated with greater follicle size of less than $10 \mathrm{~mm}$, Class II follicles associated with greater follicle production from $10 \mathrm{~mm}$ to $25 \mathrm{~mm}$, and Class III follicles associated with higher production of larger follicles than 25mm (Fig.3). Although the higher Classes follicles produced larger sized follicles, these larger sized follicles occurred in smaller quantities than the smaller ones.

\section{Assessment of sexual maturity}

All females were considered sexually mature because they had an ovarian stroma that was vascularized and had vitellogenic follicles $(0.3-3.0 \mathrm{~mm}$ in diameter), corpora lutea and albicans, and distended and sinuous oviducts with or without eggs.

\section{Morphology of the reproductive organs and ovarian follicles}

The reproductive apparatus was composed by a pair of ovaries and oviducts located dorsally within the coelomates cavity, caudally to the pleuroperitoneal cavity and suspended

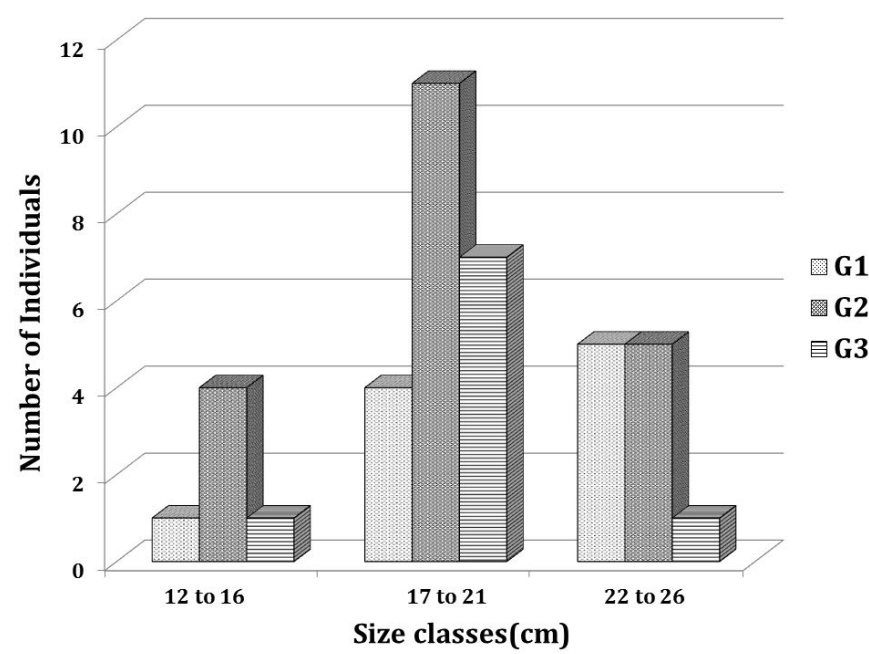

Fig.1. Distribution of size classes according to the maximum carapace length of Trachemys scripta elegans from the Wild Animals Triage Center (CETAS) of the "Parque Ecológico do Tietê", Guarulhos/SP.

Table 1. Averages \pm standard error for the analyzed variables among the different groups of Trachemys scripta elegans from the Wild Animals Triage Center (CETAS) of the Tietê Ecological Park, Guarulhos/SP

\begin{tabular}{|c|c|c|c|}
\hline \multirow{2}{*}{ Variable } & \multicolumn{3}{|c|}{ Groups } \\
\hline & G1 & G2 & G3 \\
\hline Corporal mass (g) & $1319.5 \pm 213.8$ & $1124.9 \pm 114.9$ & $1164.6 \pm 189.4$ \\
\hline Maximum carapace length $(\mathrm{cm})$ & $21.3 \pm 1.5$ & $19.6 \pm 1.1$ & $19.6 \pm 1.1$ \\
\hline Maximum carapace width $(\mathrm{cm})$ & $16.2 \pm 1.1$ & $15.3 \pm 1.0$ & $14.5 \pm 2.2$ \\
\hline Maximum plastron length $(\mathrm{cm})$ & $19.4 \pm 1.5$ & $18.3 \pm 0.8$ & $19.0 \pm 1.2$ \\
\hline Maximum plastron width (cm) & $12.1 \pm 1.2$ & $11.6 \pm 0.6$ & $11.7 \pm 0.7$ \\
\hline Post-cloacal length (cm) & $2.8 \pm 0.2$ & $2.7 \pm 0.3$ & $2.6 \pm 0.3$ \\
\hline Heigth $(\mathrm{cm})$ & $7.8 \pm 1.0$ & $7.6 \pm 0.6$ & $7.5 \pm 0.9$ \\
\hline Right ovary mass (g) & $7.5 \pm 3.1$ & $13.0 \pm 3.0$ & $15.8 \pm 5.9$ \\
\hline Right ovary length (cm) & $12.7 \pm 1.8$ & $12.3 \pm 1.9$ & $12.6 \pm 3.7$ \\
\hline Left ovary mass (g) & $10.0 \pm 4.8$ & $18.6 \pm 3.6$ & $19.2 \pm 5.1$ \\
\hline Left ovary length (cm) & $14.3 \pm 2.3$ & $14.6 \pm 1.8$ & $14.5 \pm 2.5$ \\
\hline Right oviduct mass (g) & $29.0 \pm 4.5^{\mathrm{b}}$ & $29.9 \pm 4.0^{\mathrm{b}}$ & $40.4 \pm 1.9^{a}$ \\
\hline Right oviduct length $(\mathrm{cm})$ & $0.11 \pm 0.01$ & $0.15 \pm 0.02$ & $0.15 \pm 0.06$ \\
\hline Right oviduct width $(\mathrm{cm})$ & $7.6 \pm 2.0^{\mathrm{b}}$ & $7.6 \pm 1.2^{\mathrm{b}}$ & $28.7 \pm 7.9^{\mathrm{a}}$ \\
\hline Right oviduct thickness $(\mathrm{cm})$ & $7.7 \pm 2.0^{\mathrm{b}}$ & $8.3 \pm 1.5^{b}$ & $30.6 \pm 10.2^{\mathrm{a}}$ \\
\hline Left oviduct mass(g) & $31.0 \pm 3.8$ & $34.3 \pm 2.5$ & $41.0 \pm 3.3$ \\
\hline Left oviduct length (cm) & $0.13 \pm 0.03$ & $0.15 \pm 0.02$ & $0.4 \pm 0.4$ \\
\hline Left oviduct width (cm) & $7.4 \pm 1.6^{\mathrm{b}}$ & $9.3 \pm 1.8^{\mathrm{b}}$ & $28.6 \pm 12.6^{\mathrm{a}}$ \\
\hline Left oviduct thickness (cm) & $7.5 \pm 1.7^{\mathrm{b}}$ & $8.9 \pm 1.9^{b}$ & $30.7 \pm 14.2^{\mathrm{a}}$ \\
\hline Gonadossomatic index (\%) & 8.33 & 15.23 & 14.67 \\
\hline
\end{tabular}

\footnotetext{
${ }^{a, b}$ Averages followed by the same lowercase letter on the same line did not differ significantly $(\mathrm{P}<0.05)$ by the Scott-Knott test.
} 
Table 2. Number of class I follicles (5-10mm), Class II (>10-25mm) and Class III ( $>25 \mathrm{~mm})$ follicles in Trachemys scripta elegans from the Wild Animals Triage Center (CETAS) of the Tietê Ecological Park, Guarulhos/SP, 2012

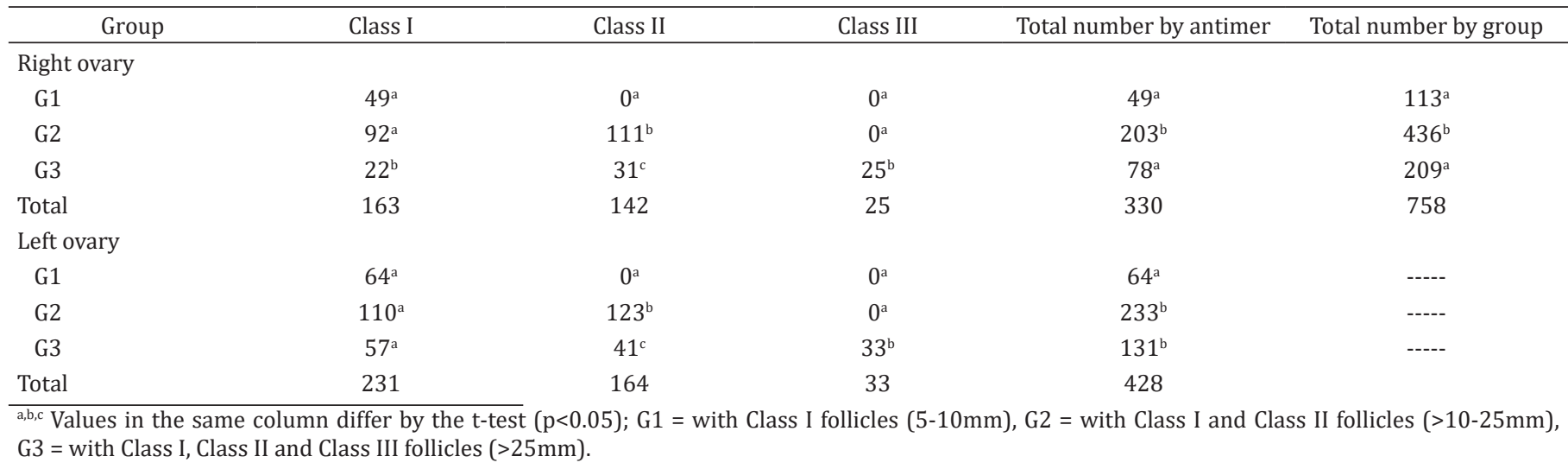

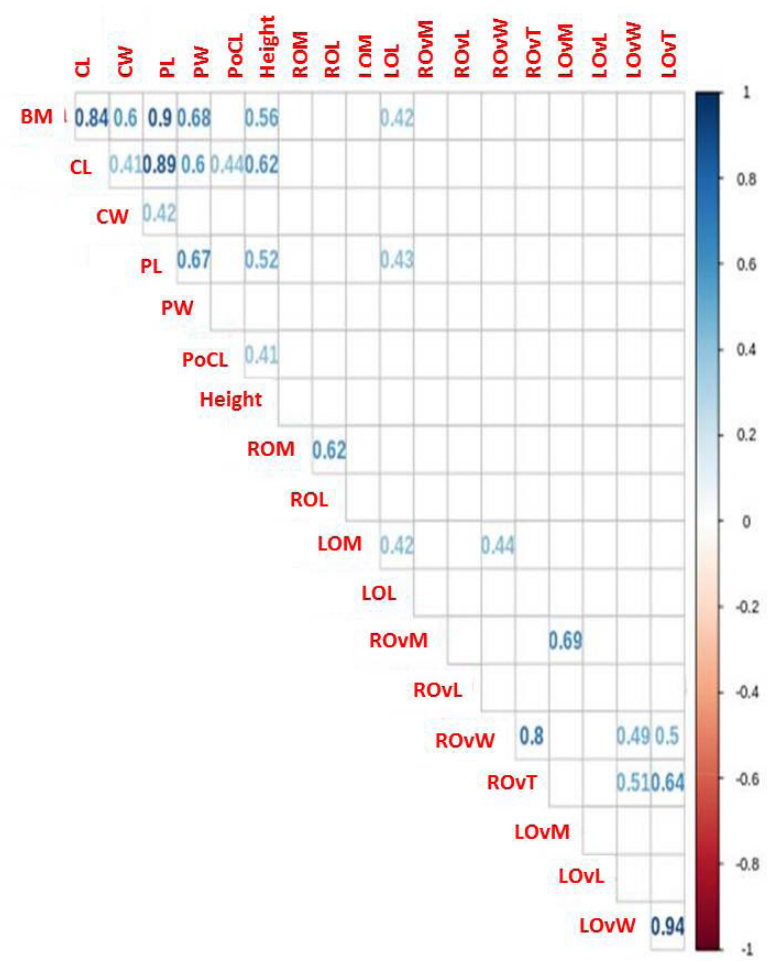

Fig.2. Significant Pearson correlation $(\mathrm{P}<0.05)$. $\mathrm{BM}=$ body mass, $\mathrm{CL}=$ maximum length of carapace, $\mathrm{CW}=$ maximum width of the carapace, $\mathrm{PL}=$ maximum length of the plastron, $\mathrm{PW}=$ maximum width of the plastron, PoCL = post-cloacal length, $\mathrm{ROM}=$ right ovary mass, ROL = right ovary length, LOM = left ovary mass, $\mathrm{LOL}=$ left ovary length, $\mathrm{ROvM}=$ right oviduct mass, $\mathrm{ROvL}=$ right oviduct length, ROvW = right oviduct width, $\mathrm{ROvT}$ = right oviduct thickness, LOvM = left oviduct mass, LOvL = left oviduct length, LOvW = left oviduct width, LOvT = left oviduct thickness.

to the ceiling of the cavity by the mesovary and mesoviduct. The ovaries were irregular structures, with the appearance of a grape bunch, arranged asymmetrically within the coelomiccavity, the left ovary is more cranial than the right ovary. The oviducts extended from the cranial end of the ovary to its insertion in the lateral wall of the cloaca, locating dorsally in each body antimer. The ovarian stroma was very small and had vitellogenic follicles at various stages of development, reaching diameters

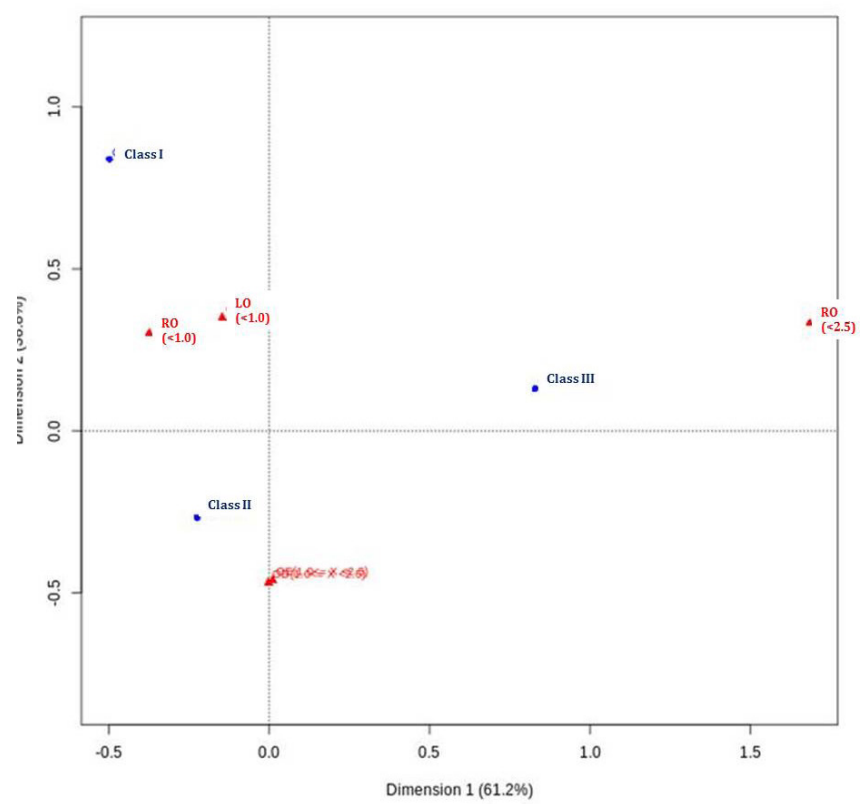

Fig.3. Correspondence analysis for association between follicle class and size of oocytes produced.

up to $30 \mathrm{~mm}$; as well as atresic follicles and corpora lutea. The oviducts were also irregular, tubular-shaped structures with the presence of lumen (Fig.4A,B). In the G3 females, eggs were observed in the oviducts, which had a varied number and diameter (Fig.4C), whose mean number was 6.44+0.69, varying from 3 to 10 eggs per female.

Histologically, the ovary had a poorly defined cortical and medullary region and stroma consisting of blood vessels, smooth muscle tissue, connective tissue, gaps, and collagen fibers. The gaps were located very close to the vitellogenic follicles and were associated with the blood vessels (Fig.5). Two ovary germ beds were observed, randomly distributed in the cortex, surrounded by connective tissue and containing ovogonies, I oocytes and primordial follicles positioned in the ovarian stroma near the highly vascularized regions, primary and secondary follicles. The primordial follicles occurred in groups of four or five and the primary scattered stroma, consisting of a single layer of epithelial cells encased in connective tissue. The secondary and tertiary follicles had 

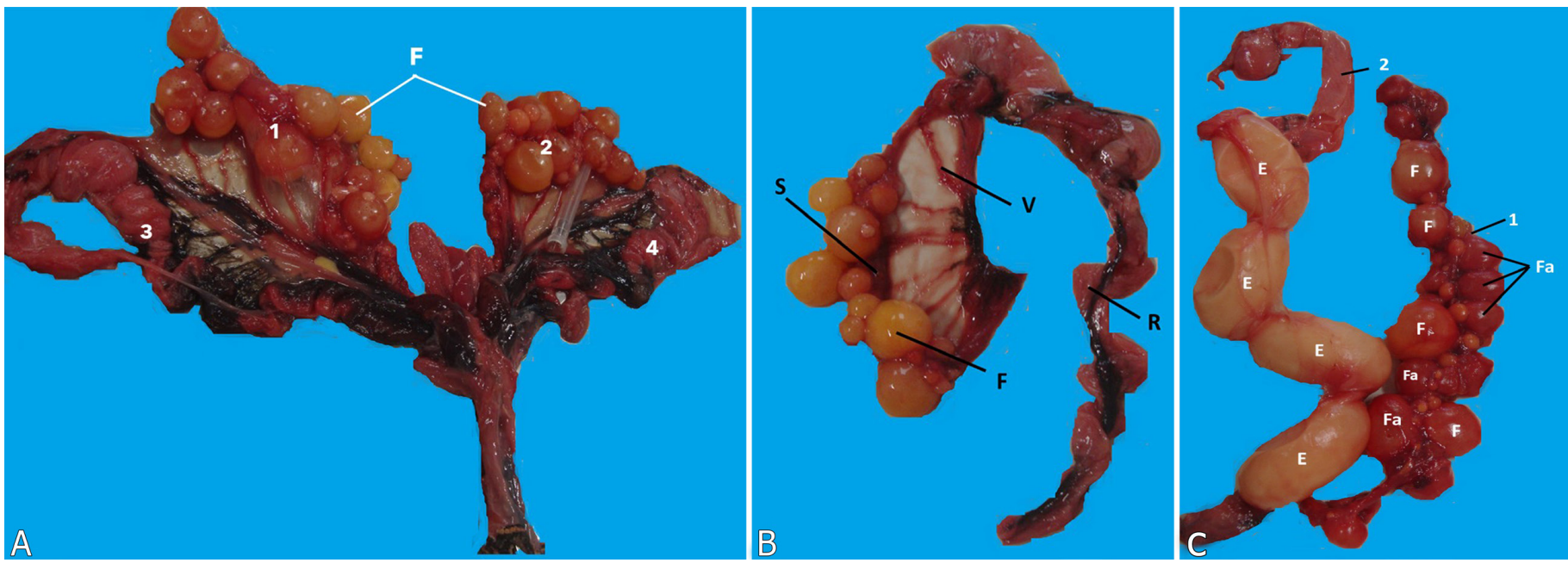

Fig.4. Representative photographs of the reproductive organs of Trachemys scripta elegans from the Wild Animals Triage Center (CETAS) of the "Parque Ecológico do Tietê", Guarulhos/SP. (A) Left (1) and right ovaries (2) filled with follicles (F) and left (3) and right oviducts (4). (B) Ovary with vitellogenic follicles (F) of different sizes on a richly vascularized (V) stroma (S) and the right oviduct (R). (C) Vitellogenic (F) and atresic follicles (Fa) in the ovary (1) and oviduct (2) with diameter increased by the presence of eggs (E).

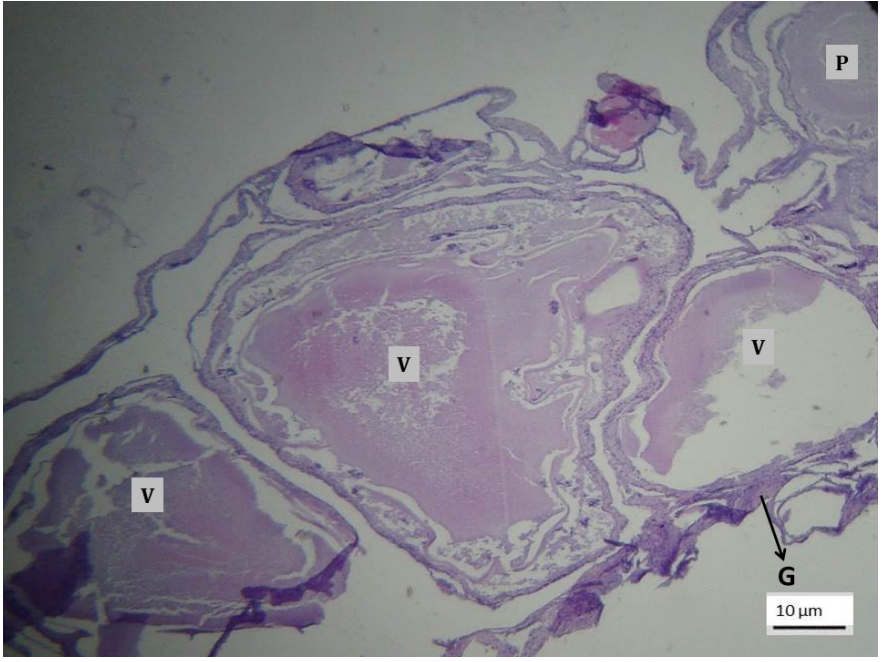

Fig.5. Photomicrography of Trachemys scripta elegans adult ovary from the Wild Animals Triage Center (CETAS) of the Tietê Ecological Park, Guarulhos/SP. Observe the poorly defined cortical and medullar regions with the presence of pre-vitellogenic $(\mathrm{P})$ and vitellogenic (V) follicles adjacent to the gaps (G).

a higher number of layers, than the primary. Tertiary follicles were wider and with more defined follicular layers (Fig.6).

Tertiary follicles presented the wall composed of four cell layers, being from the outer to the inner surface: outer theca, inner theca, granular layer with perivitelline membrane and radiate zone with the vitelline membrane (Fig.7).

The ovarian stroma also displayed coporalutea, whose color was translucent white, and atretic follicles at different stages of regression, which differed from the developing (yellow) follicles by their pink or reddish-brown coloration (Fig.8).

The oviducts were subdivided into five anatomical regions: infundibulum, uterine tube (magnum), isthmus (transition region), uterus and vagina. The infundibulum was the most cranial region and presented an ostium in the portion near

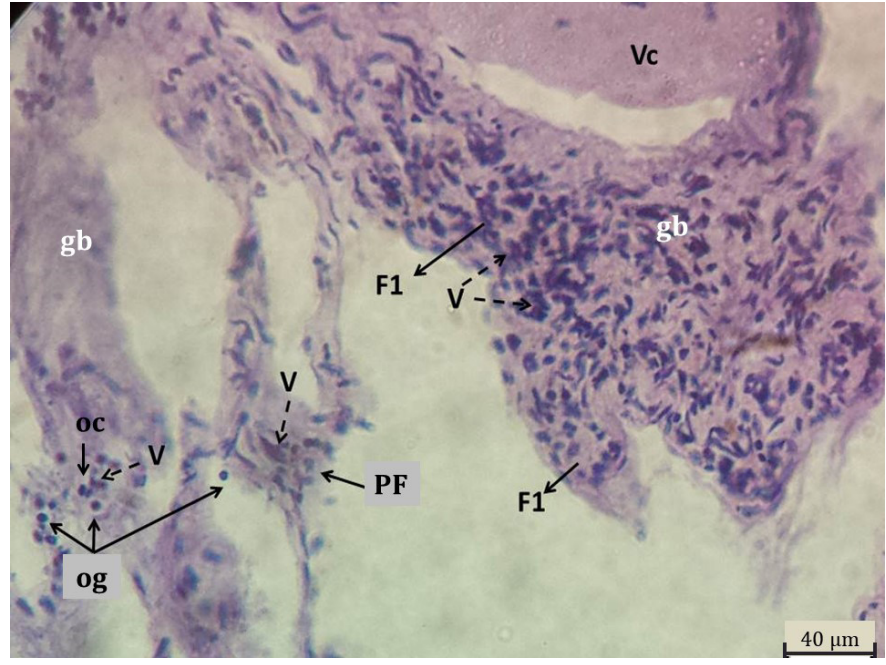

Fig.6. Photomicrography of Trachemys scripta elegans adult ovary from the Wild Animals Triage Center (CETAS) of the "Parque Ecológico do Tietê", Guarulhos/SP. In this picture we shall observe the germinative beds (gb) with ovogonies (og), oocytes I (oc) positioned in the ovarian stroma near the highly vascularized regions (V); primordial follicles (PF); primary follicles (F1) and also a tertiary follicle in the second stage of development (Vc) characterized by the presence of vacuoles in the cytoplasm, with no uniform distribution or evident granules.

the cranial end of the ovary. This portion of the oviduct is responsible for capturing the oocyte released at the time of ovulation. The uterine or major tuba was the largest segment and attached the non-glandular segment to the glandular segment represented by the isthmus. The uterus was responsible for the production of the eggshell, and the vagina, the final portion of the oviduct, was attached to the cloaca and was the thickest segment (Fig.9A).Histologically the uterine tube had a serous layer, which enveloped the entire region externally and was composed by a thin layer of loose connective tissue covered by a layer of pavement epithelium. 


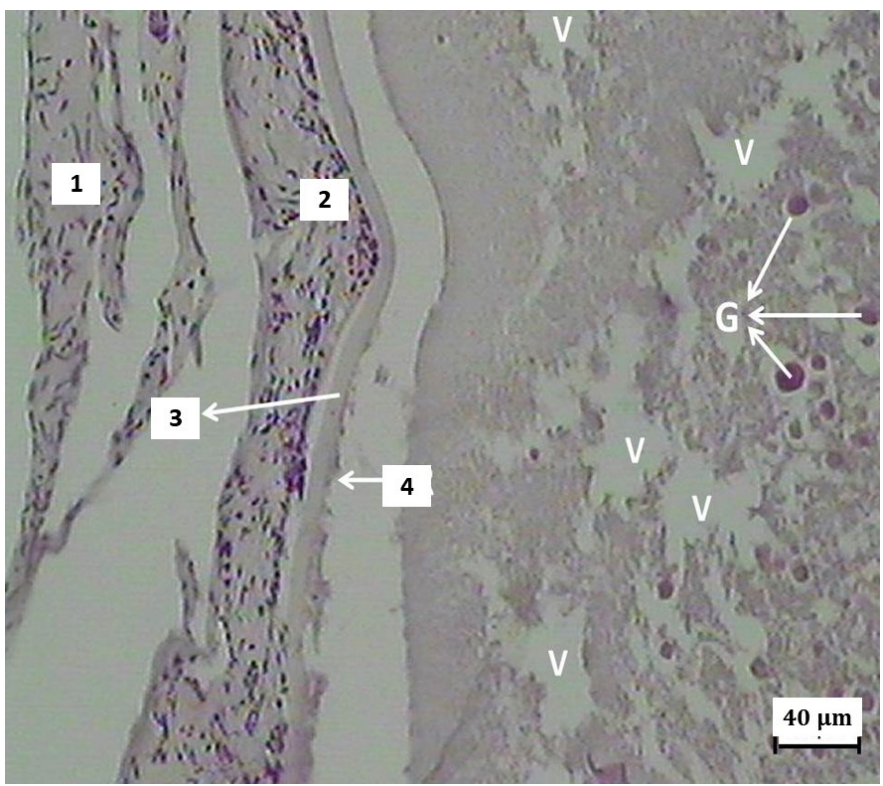

Fig.7. Photomicrography of the tertiary follicle wall of an oocyte in the third stage (Vp) of Trachemys scripta elegans development from the Wild Animals Triage Center (CETAS) of the "Parque Ecológico do Tietê", Guarulhos/SP. Outer theca layer (1), inner theca layer (2), granular layer with the perivitelline membrane (3), radial zone with vitelline membrane (4) and presence of vacuoles $(\mathrm{V})$ and apparent granules $(\mathrm{G})$ in the oocyte cytoplasm.

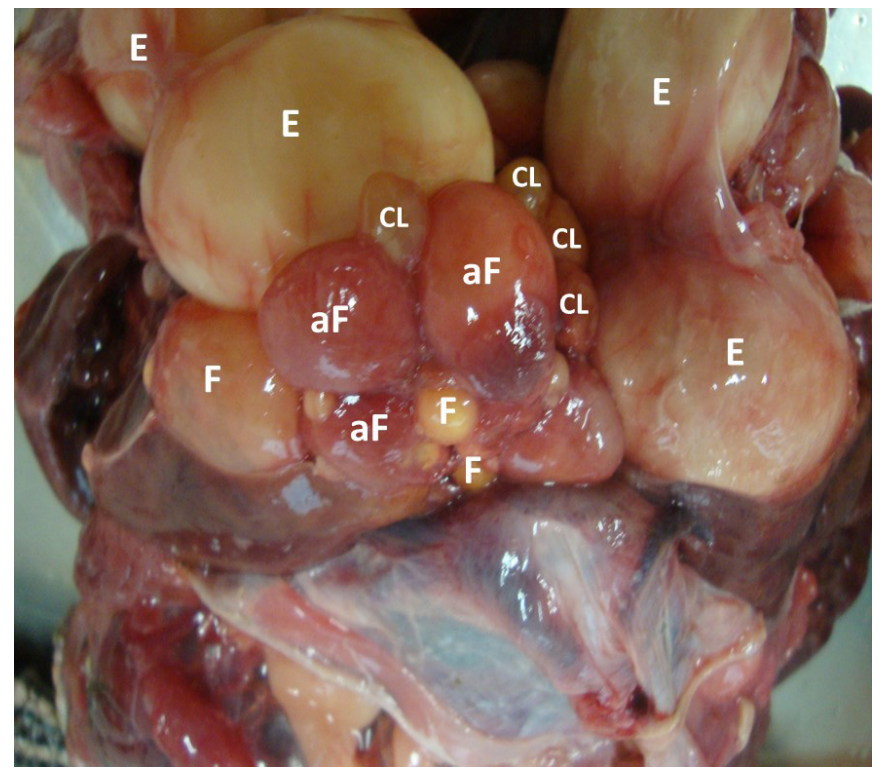

Fig.8. Right ovary, and both right and left oviducts of Trachemys scripta elegans from the Wild Animals Triage Center (CETAS) of the "Parque Ecológico do Tietê", Guarulhos/SP. Vitellogenic follicles at different stages of development (F), atretic follicles (aF), corpora lutea (CL) and eggs (E) in oviducts.

The muscular layer was composed of longitudinally arranged smooth muscle fibers and a well-developed mucosal layer, with a cylindrical pseudostratified epithelium with ciliary, mucus-secretory and basal cells, and lamina propria of loose connective tissue, with the presence of vessels and numerous tubular glands (Fig.9B).

\section{Evaluation of the stage of oocyte development}

In the gonadal tissue, there were oocytes at the following stage of development: initial stage (Ho) (Fig.10A), second stage (Vc) (Fig.10-B) and third stage (Vp) (Fig.10C,D). Follicles in the fourth stage $(\mathrm{Gr})$ were not visible.

\section{DISCUSSION}

There are just a few studies dealing on the biology and capacity reproductive of turtles involving gonadal analysis and egg production. Some of them are restricted to the natural environment and with low number of specimen of adult females (Martinez-Silvestre 1997, Lutz et al. 2003, Rosa 2009, Chaves et al. 2012) or newly hatched individuals (Malvasio et al. 1999, Lutz et al. 2003, Wyneken et al. 2007, Ceriani \& Wyneken 2008, Malvasio et al. 2011). Few other studies analyze adult females in an unnatural environment (Bertolero \& Canicio 2000, Capalleras \& Carretero 2000, Cadi et al. 2004, Vieira \& Costa 2006). Given the deficiency of information about this species outside its natural habitat, the present study described for the first time the ovarian and oviductal characteristics of Trachemys scripta elegans bred in the Brazilian Cerrado correlating these findings with the size of the specimens, sexual maturity, and reproductive capacity.

The absence of significant difference in body biometry between groups (Table 1) suggested that all females were in the same stage of body development, with most females exhibiting from 17.00 to $21.00 \mathrm{~cm}$ maximum carapace length (Fig.1). Average body mass values did not differ from Perez-Santigosa et al. (2008) and Gradela et al. (2017a), but were slightly higher than Vieira \& Costa (2006); lower than those of Gradela et al. (2017b) and well above those of Taniguchi et al. (2017). The maximum carapace length did not differ from Perez-Santigosa et al. (2008) and Gradela et al. (2017a, 2017b), but was slightly higher than described by Vieira \& Costa (2006) and lower than Taniguchi et al. (2017). In all groups, there was a positive and harmonic development among mass, carapace, and plastron, which were positively correlated. These data corroborate with the results of Gradela et al. (2017b) and diverge from Gradela et al. (2017a) who observed development uniformity only between body mass and carapace length and width of the plastron, and between the carapace and plastron lengths.

In T. scripta females the sexual maturity is influenced mainly by body size and not by age (Gibbons \& Greene 1990), so that females mature with plastron length from 16.00 to $17.00 \mathrm{~cm}$ (Perez-Santigosa et al. 2008) and of $16.70 \mathrm{~cm}$ in the subspecies T. scripta elegans (Tucker \& Moll 1997) when they reach three to four years of age (Pupins 2007). Studies performed in Southern Spain describe that some females reach sexual maturity at the length of $15.95 \mathrm{~cm}$ and age of three years, displaying similar or even higher growth rates than those in the native habitats (Perez-Santigosa et al. 2008). Our study highlights a similar situation, as the smallest female had a maximum carapace length of $12.4 \mathrm{~cm}$.

Some papers suggest that only carapace length is considered as indicative of sexual maturity. This orientation shall be deemed inappropriate: among populations and even within a population there is a difference in the minimum size of the individuals at the beginning of reproduction (Limpus etal.1994). Duarte et al. (2011) point out that the stages of maturation of females are associated with the yelk deposition in ovarian 

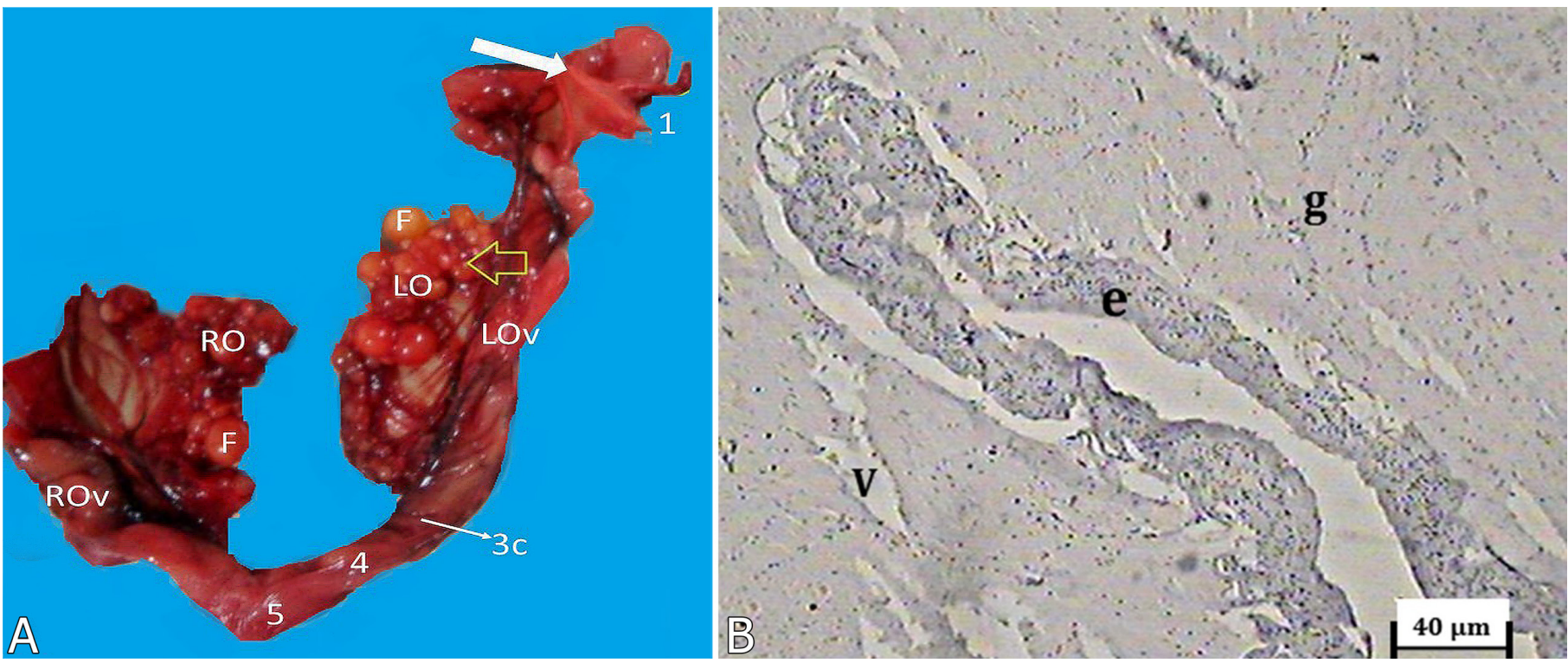

Fig.9. Oviduct of Trachemys scripta elegans from the Wild Animals Triage Center (CETAS) of the "Parque Ecológico do Tietê", Guarulhos/SP. (A) Right (RO) and left (LO) ovaries filled with follicles (F); right (ROv) and left oviducts (LOv) and oviduct regions: infundibulum (1) with infundibularostium (broad arrow, 2); isthmus (3), uterus (4) and vagina (5). (B) Histological section of the uterine tube showing the mucosa layer consisting of pseudostratified cylindrical epithelium (e), tubular glands (g) and vessels (v). HE, obj.40x.

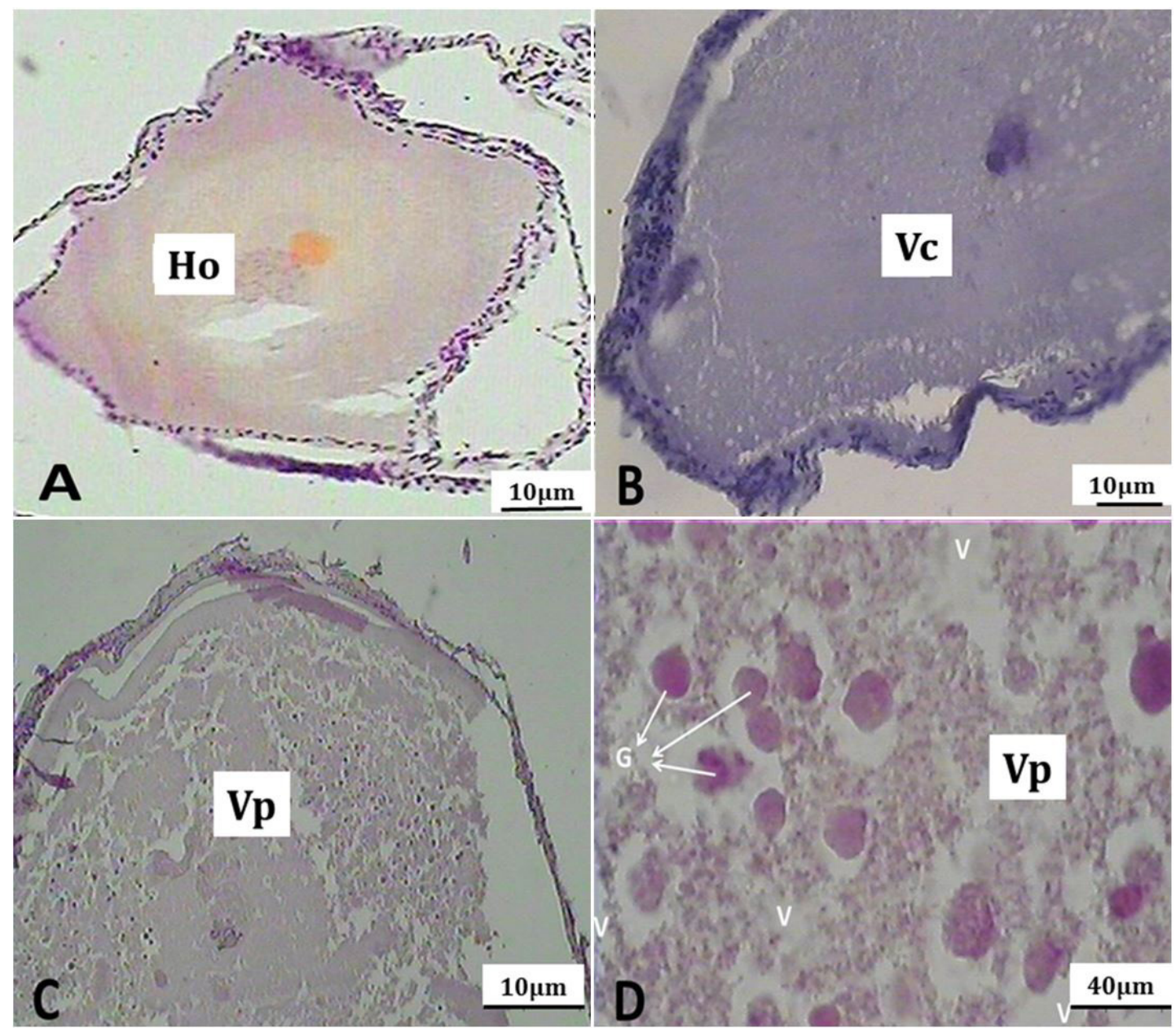

Fig.10. Photomicrography of Trachemys scripta elegans oocytes from the Wild Animals Triage Center (CETAS) of the "Parque Ecológico do Tietê", Guarulhos/SP. (A) Oocyte in the initial stage (Ho) presenting homogeneous cytoplasm. (B) Oocyte in the second stage (Vc) with the presence of vacuoles (V) in the cytoplasm. (C,D) Oocyte in the third stage (Vp) with the presence of vacuoles (V) and apparent granules $(G)$ in the cytoplasm. 
follicles. In reptiles, turtles (Machado Júnior et al. 2006) and birds (Dyce et al. 2004) the yelk serves as a nutritive matter to the embryo throughout its development within the egg and its production and secretion are stimulated by estrogen (Rosanova et al. 2002), which is released after puberty and acts locally in the ovarian cortex and medulla promoting the differentiation of gonads (Pieau \& Dorizzi 2004) and oviducts (Owens \& Morris 1985). This study associates the analysis of the length of the carapace with the presence of vitellogenic follicles, athreptic follicles, corpora lutea and corpus albicans in the ovaries and distended and sinuous oviducts with or without the presence of eggs as indicative of sexual maturity (Ernst 1971, Wyneken 2001, Limpus \& Limpus 2003, Castro 2006, Rossi et al. 2006, Delgado 2006, Chaves et al. 2012). In this paper, the results showed that all females were sexually mature regardless of the maximum length of the carapace.

The reproductive status of a population can be estimated by analyzing the gonadal status of females (Delgado 2006). In this sense, the gonadosomatic index (GSI) has been used as an indication of the functional status of ovaries in fish (Querol et al. 2002, Costa et al. 2005, Zeyl et al. 2013), because it usually increases with the increase of the gonadal stage (Nascimento et al. 2012, Zeyl et al. 2013), and the highest values observed in the mature stage (Nascimento et al. 2012), as in the females in this study that has shown active vitellogenesis (Querol et al. 2002). Therefore, the gonadosomatic index proved adequate as an indicator of the reproductive period of T. scripta elegans, whose mean values were significantly higher than those of Kinosternon scorpioides (Chaves et al. 2012).

A pair of ovaries and oviducts represented the female genital organs of T. scripta elegans, attached to the ceiling of the celoma cavity, respectively, by the mesovarium and mesoviduct, as described in other species of turtles (Wyneken 2001, Machado Júnior et al. 2006, Chaves et al. 2012, Pérez-Bermúdez et al. 2012, Silva et al. 2017) and reptiles (Storer et al. 2000), which differ from birds that have only developed left oviduct (Dyce et al. 2004). The ovaries presented a topographic layout, appearance, and presence of yellow-colored follicles at different stages of development similar to those of sea turtles (Wyneken 2001); K. scorpioides (Machado Júnior et al. 2006, Chaves et al. 2012), Chelonia mydas (Kondak 2012) and Eretmochelys imbricata (Pérez-Bermúdez et al. 2012). The asymmetric position of the ovaries, caused by differences in volume and quantity of follicles, corroborated with Chaves et al. (2012) disagreeing with the symmetry observed by Storer et al. (2000) and Machado Júnior et al. (2006).

No significant difference was observed in the ovarian mass between the studied groups. The total number of follicles did not differ statistically between the right (330) and left (428) antimeres. This finding was in opposition to that described in K. scorpioides. In this species the right ovary was larger than the left due to the higher number of vitellogenic follicles (Chaves et al. 2012). The average mass of right and left ovaries in the G1 groups (7.46 and 9.99g, respectively); G2 (13.01 and 18.57g) and G3 (14.58 and $14.45 \mathrm{~g}$ ) were higher than those of $K$. scorpioides (6.25 $\pm 4.23 \mathrm{~g}$ and $2.27 \pm 1.42 \mathrm{~g}$, respectively) (Chaves et al. 2012), while Velasquez \& Vogt (2011) observed in Peltocephalus dumerilianus values ranging from 1.31 to $48.25 \mathrm{~g}$ and 1.21 to $45.66 \mathrm{~g}$, respectively. In T. scripta elegans the presence of enlarged or pre-ovulatory follicles, eggs or distended oviducts, suggest recent oviposition (Perez-Santigosa et al. 2008) and, after the oviposition period, no eggs or follicles larger than $21 \mathrm{~mm}$, but only follicles of 7 to $13 \mathrm{~mm}$, and in a small proportion of females, also a few pre-ovulatory follicles of $14-20 \mathrm{~mm}$, corroborating with those observed in groups G1 and G2, respectively.

The significant relationship between female size (body mass and plastron length) and left ovary length suggested that the gonadal growth was concomitant with the body growth, and supported the existence of a positive relationship between brood size and female size as described in other species (Ceriani \& Wyneken 2008, Delgado 2006, Velasquez \& Vogt 2011, Failla et al. 2018), but different from sea turtles (Hamann etal.2003) and C. mydas juveniles Rosa $(2005,2009)$.

The presence of follicles of different diameters ( $<5 \mathrm{~mm}$ up to $>25 \mathrm{~mm}$ ), as well as corpus luteum and eggs in the oviducts, highlighted a similarity of follicular development among specimen of the same species (Perez-Santigosa et al. 2008) and other species (Ramo 1982, Velasquez \& Vogt 2011) and reflected the ovarian complexity of the analyzed females, which ranged from the beginning of the period of ovarian maturation to the presence of eggs and corpus luteum. These findings denote the presence of ovarian follicular hierarchy (Velasquez \& Vogt 2011) characterized by the presence of follicles at all maturation stages, including also not-vitellogenic follicles (Etches \& Petitte 1990). This hierarchy can be accepted as a reproductive strategy to keep the highest possible number of follicles available and thus reduce the probability of losses caused by excessive and effective ovulation, making a possible rapid ovarian recovery and ensuring maximum reproduction of females at each station. In chelonians, these characteristics may increase as a function of the size of the female (Velasquez \& Vogt 2011), as observed in G2, which presented a significant number of follicles (Table 2).

The follicular development in reptiles divides into two phases: pre-vitellogenic and vitellogenic, which is characterized by the accumulation of yolk inside the oocyte. Pre-vitellogenic follicles are small and white. As they enter the vitellogenic stage become yellow and large (Jacobson 2007). It should be noted that, although follicles of 5-6 $\mathrm{mm}$ become vitellogenic, and those of $16-18 \mathrm{~mm}$, pre-ovulatory, in most animals some vitellogenic follicles do not reach pre-ovulatory size and, in some cases, those of pre-ovulatory size do not ovulate by becoming atretic (Kuchling \& Bradshaw 1993), as observed in this study, because although the larger Classes produced larger follicles, they occurred in a smaller number, since some became atretic. These follicles differed from vitellogenic follicles by pink or reddish-brown coloration (Fig.8), similar to that described in Chelodina rugosa and Elseya dentata (Kennett 1999).

In T. scripta elegans small and large follicles were also distributed throughout the ovary, with neither elongation of the largest cranial nor the concentration of the smaller and immature in the posterior third of the ovary as described in marine turtles (Wyneken 2001, Flint et al. 2009). On the other hand, larger follicles ( $>25 \mathrm{~mm}$ ) occurred in post-ovulatory females, that is, G3, agreeing with other species (Dobie 1971, Iverson 1979) since a new wave of ovulation usually occurs $36 \mathrm{~h}$ after a oviposition (Wibbels et al. 1990). Therefore, in T. scripta elegans the presence of follicles of different sizes in the ovaries suggests that at least up to four clutches annually may be produced (Perez-Santigosa et al. 2008). 
The presence of increased cytoplasm in the oocytes indicates their development phase, with the follicles more developed being those with cytoplasmic vacuoles or granules, which characterize the nutrient reserve in the cell and indicate the onset of vitellogenesis (Kondak 2012). In this study, the analysis of the gonadal tissue highlighted three stages of oocyte development according to the structure of the cytoplasm: homogeneous (Ho), vesicular (Vc) and vesicular in the cortex with apparent granules (Vp). Our observations agreed with Kondak (2012) disagreeing with Rosa (2005) who also observed the fourth stage (Gr) characterized by the presence of granular oocytes and increased cytoplasm.

After complete maturation of the oocytes and before mating, a group of mature follicles is ovulated together (Mateus 2014). The oocytes are picked up by the fimbriae of the region of the oviduct infundibulum from where they pass into the non-glandular segment, and enter the uterine tube (magno), where they remain for about three days and are covered by a layer of albumin.Later on, the oocytes go to the glandular region and, after secretion of proteins and membrane carbohydrates (corium) and a matrix of aragonite, they become eggs. After six to seven days, these eggs undergo calcification and are deposited in the vagina, where they remain for several days until they go to the cloaca and are spawned (Wyneken 2001, McArthur 2008). Concomitantly to ovulation, the cells of the follicle wall hypertrophy and the corpus luteum develops (Mateus 2014). This structure resembles, in some aspects, those of some species of mammals (Guillette Junior et al. 1995) and has as their key function, the preservation of the pregnancy or of the eggs which are developing inside the oviducts (Gemmell 1995). For this reason, the higher activity of the corpus luteum coincides with the formation of external membranes in the oviducts (Altland 1951), which explains their regression shortly after (Velasquez \& Vogt 2011) or up to three months after spawning in the genera Pseudemys and Graptemys (Webb 1961). In T. scripta elegans corpus luteum were visualized in females with eggs inside the oviducts and were distinguished from the follicles by their translucent white coloration (Fig.8) as in sea turtles (Owens 1980). According to these authors, corpus luteum produces and secretes progesterone in response to the luteinizing hormone, similar to mammals and birds (Hafez \& Hafez 2004), and this has the function of stimulating the production of albumin. During the reproductive season, the corpora lutea regress and become albicans bodies (Wyneken 2001, Jacobson 2007) corroborating findings in mammals and birds (Hafez \& Hafez 2004).

Microscopically reduced ovarian stroma and non-differentiation between the cortical and medullary regions agreed with and K. scorpioides (Chaves et al. 2012), diverging from mammals, presenting these easily recognizable regions (Hafez \& Hafez 2004) and birds, which have the most discrete and diffuse medullar region (Banks 1992). In contrast to mammals, where the vascularization is restricted to the medullar region (Hafez \& Hafez 2004), in T. scripta elegans, the vascularization of the ovary is widespread throughout the stroma, which is composed of pre-vitellogenic follicles, vitellogenic, blood vessels, gaps, germinal beds, connective tissue and smooth muscle as in other Testudines (Chaves et al. 2012, Pérez-Bermúdez et al. 2012).
The observation of two germinative beds per ovary corroborates with similar observations performed in other species of reptiles, Pseudemys scripta elegans, Coturnix coturnix japonica (Callebaut et al. 1997) and lizards (Radder \& Shine 2007) and diverging from E. imbricata (Pérez-Bermúdez et al. 2012), C. mydas and C. caretta (Aitken et al. 1976) that have multiple beds. The arrangement of the primordial follicles in germ beds, in groups of four or five, differed from ostrich, in which they usually occur alone (Madekurozwa \& Kimaro 2006). Morphology and distribution of primary, secondary and tertiary follicles were similar to K. scorpioides (Chaves et al. 2012), with the primary follicles being close to blood vessels and some dispersed in the stroma, while in E. imbricata these are distributed randomly in the cortex (Pérez-Bermúdez et al. 2012). The constitution of the wall of the tertiary follicles, formed by external theca, internal theca, granular layer with perivitelline membrane and radial zone with vitelline membrane did not diverge from K. scorpioides (Chaves et al. 2012); snakes (Almeida-Santos 2005) and ema (Parizzi et al. 2007).

According to Callebaut et al. (1997), in T. scripta elegans gaps are smaller and histochemically more homogeneous than in E. imbricata (Pérez-Bermúdez et al. 2012) and Pelodis cussinensis (Nainan et al. 2009), which have the most developed and histochemically polymorphic lacunar system. In common with these species, the gaps in T. scripta elegans were also located very close to the follicles and were associated with blood vessels. This positioning seems to be related to its function, since they represent space for the follicular expansion during the maturation (Pérez-Bermúdez et al. 2012), besides being escape route for the increase of the blood pressure in the ovary (Callebaut 1988) and have paper in follicular nutrition (Chen et al. 1998).

There are few studies on reptiles addressing the structure and function of the oviduct, particularly in turtles. T. scripta elegans, like most reptiles, exhibits both functional and separate oviducts, having the only junction in their final portion to form a cloaca (Fox 1977), diverging from birds that only have the left oviduct developed (Dyce et al. 2004). The topography of the oviducts, beginning near the cranial end of the ovaries and extending laterally to the insertion in the cloaca, agreed with previous reports (Wyneken 2001, Machado Júnior et al. 2006, Silva et al. 2017) and the anatomical division in five regions: infundibulum, uterine tube, isthmus, uterus, and vagina, agreed with other reptiles (Girling 2002), turtles (Alkindi et al.2006, Machado Júnior et al. 2006, Firmiano et al. 2012, Silva et al.2017) and birds (Girling 2002, Parizzi 2006), but diverged from lizards (Guillette Junior et al. 1989, Girling et al. 1997), snakes (Perkins \& Palmer 1996), and geckos (Sever et al. 2000). In these species the oviducts are subdivided into three or four regions.

Similar to P. geoffroanus (Firmiano et al. 2012); reptiles (Sever et al. 2000, Nogueira et al. 2011) and mammals (Junqueira \& Carneiro 2008), T. scripta elegans presented the histological structure of the uterine tube constructed of serosa, muscular and mucosa. The uterine tube region was similar to P. geoffroanus (Firmiano et al. 2012) and the abundance of glands in the mucosal layer, which are responsible for the production of albumin (Firmiano et al. 2012), agreed with other species of turtles and crocodilians (Aitken et al. 1976, Palmer \& Guillete Junior 1988, Girling 2002, Firmiano et al. 2012). 
In T. scripta elegans out of its natural distribution there is little information about its reproductive capacity (Cadi et al. 2004), and egg deposition has been observed in countries such as Spain (Bertolero \& Canicio 2000, Capalleras \& Carretero 2000, Bringsøe 2001, Pleguezuelos 2004), France (Cadi et al. 2004), Italy (Ferri \& Soccini 2003, Crescente et al. 2014) and Taiwan (Chen \& Lue 1998) and now also demonstrated for the first time in Brazil. According to Vieira \& Costa (2006), although the population of T. scripta elegans studied in Brasilia-DF was in reproductive condition, no cut rituals, nests or other signs of reproduction were observed, indicating that it was stagnant and its growth was due to the release of the individuals by the visitors of the Park. Rossi et al. (2006), although they observed the opening of pits, also did not observe the oviposition of eggs in the T. scripta elegans raised in captivity in São Paulo (SP). This finding is important because evidence of breeding in introduced species is critical to understanding their impact on invaded ecosystems (Cadi et al. 2004). In a natural environment, T. scripta elegans can lay up to six clutches each year, with 2 to 30 eggs each and a variable incubation period of 59 to 112 days (Ernst et al. 1994, Bringsøe 2006). However, in an unnatural environment the egg production can vary from 2 to 11 (Cadi et al. 2004), 1 to 16 (Crescente et al. 2014); 1 to 19 (Taniguchi et al. 2017) or in an average of 11.5 eggs (Perez-Santigosa et al. 2008) as in this study, being lower than that of North American specimens producing 12.7 to 15.1 eggs (Tucker et al. 1998) or, on average, 10.5 (Ernst \& Lovich 2009). In this study there was no significant difference in the number of eggs among the oviducts, agreeing with Velasquez \& Vogt (2011) and disagreeing with Legler (1960), as well as no significant difference in egg size, as in other species of chelonians (Tucker \& Janzen 1998). The presence of eggs in G3 oviducts was responsible for the greater width of this organ in the right antimer and the greater mass and width in the left antimer (Table 1).

\section{CONCLUSIONS}

In Trachemys scripta elegans the sexual maturity should be established based on ovarian evaluation and not on maximum carapace length. The structure of the ovary resembles that of other species of oviparous reptiles and can be used for phylogenetic morphological comparisons. In addition, the gonadal-somatic index is an adequate indicator of the reproductive period; there is a relationship between body and gonadal growth, and therefore between brood size and size of female. Ovaries with pre and vitellogenic follicles of different diameters, luteal bodies and the presence of eggs in the oviducts reflect the ovarian complexity of this specie and denote a follicular hierarchy.

The results of the present study described the characteristics of the ovaries, oviducts and uterine tubes of T. scripta elegans created in the Brazilian Cerrado demonstrating that reproduction occurs in this environment. Through this knowledge, essential and relevant information is available to understand their impact on the invaded ecosystems and to establish eradication programs, since the extraction of adult females associated with the knowledge of their reproductive capacity can contribute to the reduction of the annual reproductive yield of this species and diminish its effect on local biodiversity.

Conflict of interest statement.- The authors declare no conflicts of interest.

\section{REFERENCES}

Aitken R.N.C., Solomon S.E. \& Amoroso E.C. 1976. Observations on the histology of the ovary of Costa Rican green turtle, Cheloniamydas L. J. Exp. Mar. Biol. Ecol. 24(2):189-204.<http://dx.doi.org/10.1016/0022-0981(76)90103-9>

Alkindi A.Y., Mahmoud I.Y., Woller M.J. \& Plude J.L. 2006. Oviductal morphology in relation to hormonal levels in the snapping turtle. Chelydraserpentine. Tissue Cell 38(1):19-33.<http://dx.doi.org/10.1016/j.tice.2005.10.001> <PMid:16384588>

Almeida-Santos S. 2005. Modelos reprodutivos em serpentes: estocagem de esperma e placentação em Crotalus durissus e Bothrops jararaca (Serpentes: Viperidae). Doctoral thesis, Faculdade de Medicina Veterinária e Zootecnia, USP, São Paulo, SP. 204p. <http://dx.doi.org/10.11606/T.10.2005.tde28062006-143529>.

Altland P.D. 1951. Observations on the structure of the reproductive organs of the box turtle. J. Morphol. 89(3):599-621.<http://dx.doi.org/10.1002/ jmor.1050890307>

Banks W.J. 1992. Histologia Veterinária Aplicada. 2ª ed. Manole, São Paulo, p.585-587.

Bertolero A. \& Canicio A. 2000. Nueva cita de nidificaciõn em libertad de Trachemys scripta elegans em Cataluña. Bol. Asoc. Herpetol. Esp. 11:84.

Bringsøe H. 2001. Trachemys scripta (Schoepff, 1792) - BuchstabenSchmuckschildkrote, p.526-583. In: Fritz U. (Ed), Handbuch der Reptilien und Amphibien Europas: Schildkro"ten (Testudines) I. AULA-Verlag GmbH, Wiebelsheim, Germany.

Bringsøe H. 2006. Invasive Alien Species Fact Sheet: Trachemys scripta. North European and Baltic Network on Invasive Alien Species (NOBANIS), Copenhagen. Available at <www.nobanis.org> Access on July 2, 2019.

Buhlmann K.A., Akre T.S.B., Iverson J.B., Karapatakis D., Mittermeier R.A., Georges A., Rhodin A.G.J., van Dijk P.P. \& Gibbons J.W. 2009. A global analysis of tortoise and freshwater turtle distributions with identification of priority conservation areas. Chelonian Conserv. Biol. 8(2):116-149. <http://dx.doi. org/10.2744/CCB-0774.1>

Cabral S.R.P., Santos L.R.S., Franco-Belussi L., Zieri R., Zago C.E.S. \& Oliveira C. 2011. Anatomy of the male reproductive system of Phrynops geoffroanus (Testudines, Chelidae). Acta Scient. Biol. Sci. 33(4):487-492.

Cadi A., Delmas V., Prévot-Julliard A.-C., Joly P., Pieau C. \& Girondot M. 2004. Successful reproduction of the introduced slider turtle (Trachemys scripta elegans) in the South of France. Aquatic Conserv: Mar. Freshw. Ecosyst. 14(3):237-246. <http://dx.doi.org/10.1002/aqc.607>

Callebaut M. 1988. The ovarian chordolacunar system in birds. Arch. Biol. 99:1-15.

Callebaut M., Van Nassauw L. \& Harrisson F. 1997. Comparison between oogenesis and related structures in a reptile, Pseudemys scripta elegans(turtle) and in a bird Coturnix coturnix japonica (quail). Reprod. Nutr. Dev. 37(3):233-252. <http://dx.doi.org/10.1051/rnd:19970301><PMid:9269708>

Capalleras X. \& Carretero M.A. 2000. Evidencia de reproducciõn com éxito en libertad de Trachemys scripta em la Península Ibérica. Bol. Assoc. Herpetol. Esp. 11:34-35.

Castro A.B. 2006. Biologia reprodutiva e crescimento do muçuã Kinosternon scorpioides (Linnaeus, 1776). Masters dissertation, Universidade Federal do Pará, Belém, PA. 100p.

Ceriani S.A. \& Wyneken J. 2008. Comparative morphology and sex identification of the reproductive system in formalin-preserved sea turtle specimens. Zoology 111(3):179-187.<http://dx.doi.org/10.1016/j.zool.2007.07.007> $<$ PMid:18234484>

Chaves E.P., Oliveira S.C.R., Araújo L.P.F., Oliveira A.S., Miglino M.A., Abreu-Silva A.L., Melo F.A. \& Sousa A.L. 2012. Morphological aspects of the ovaries of turtle Kinosternon scorpioides raised in captivity. Pesq. Vet. Bras. 32(7):667671. <http://dx.doi.org/10.1590/S0100-736X2012000700015> 
Chen F.Y., Hua T.M. \& Chen B.H. 1998. Studies on the histochemical analysis of the eggs of Pelodiscus sinensis. J. Anhui. Agric. Sci. 21:232-244.

Chen T.-H. \& Lue K.-Y. 1998. Ecological notes on feral populations of Trachemys scripta elegans in northern Taiwan. Chelonian Conserv. Biol. 3:87-90.

Costa A.P.R., Andrade D.R., Vidal Junior M.V. \& Souza G. 2005. Indicadores quantitativos da biologia reprodutiva de fêmeas de piau-vermelho no Rio Paraíba do Sul. Pesq. Agropec. Bras. 40(8):789-795. <http://dx.doi. org/10.1590/S0100-204X2005000800009>

Crescente A., Sperone E., Paolillo G., Bernabò I., Brunelli E. \& Tripepi S. 2014. - Nesting ecology of the exotic Trachemys scripta elegans in an area of Southern Italy (Angitola Lake, Calabria). Amphib.-reptil. 35(3):366-370. <http://dx.doi.org/10.1163/15685381-00002955>

Delgado C.M.N. 2006. Gonad development and hormone titres in Loggerrhead Sea Turtles (Caretta caretta) in the NE Atlantic. Doctoral thesis, Universidade da Madeira, Funchal, Portugal. 150p.

Dobie J.L. 1971. Reproduction and growth in the alligator snapping turtle, Macroclemys temmincki (troost). Copeia 1971(4):645-658. http://dx.doi. org/10.2307/1442633.

Duarte D.L.V., Monteiro D.S., Jardim R.D., Soares J.C.M. \& Varela-Junior A.S. 2011. Determinação sexual e maturação gonadal de fêmeas de tartaruga-verde (Chelonia mydas) e tartaruga-cabeçuda (Caretta caretta) no extremo sul do Brasil. Acta Biol. Parana 30(3/4):87-103. <http://dx.doi.org/10.5380/ abpr.v40i(1-4).25130>

Dyce K.M., Sack W.O. \& Wensing C.J.G. 2004. Tratado de Anatomia Veterinária. Elsevier, Rio de Janeiro.

Ernst C.H. 1971. Sexual cycles and maturity of the turtle, Chrysemys picta. Mar. Biol. Lab. 140(2):191-199. <http://dx.doi.org/10.2307/1540068>

Ernst C.H. \& Barbour R.W. 1989. Turtles of the World. Smithsonian Institution Press. Washington, D.C. 313p.

Ernst C.H. \& Lovich J.E. 2009.Turtles of the United States and Canada. Johns Hopkins Univ. Press, Baltimore.

Ernst C.H., Lovich J.E. \& Barbour R.W. 1994. Turtles of the United States and Canada. Smithsonian Institution Press, Washington and London.

Etches R.J. \& Petitte J.N. 1990. Reptilian and avian follicular hierarchies: models for the study of ovarian development. J. Exp. Zool. Suppl. 4:112122. <http://dx.doi.org/10.1002/jez.1402560419><PMid:1974772>

Failla G., Calais Júnior A., Pavanelli L. \& Nunes L.C. 2018. Histomorphometric analysis of gonads of green turtles (Cheloniamydas) stranded on the coast of Espírito Santo state, Brazil. Arq. Bras. Med. Vet. Zootec. 70(1):213-221. <http://dx.doi.org/10.1590/1678-4162-9431>

Ferreira A. \& Dolder H. 2003. Sperm ultrastructure and spermatogenesis in the lizard, Tropidurusitambere. Biocell 27(3):353-362.<PMid:15002752>

Ferri V. \& Soccini C. 2003. Riproduzione di Trachemys scripta elegans in condizioni semi-naturali in lombardia (Italia settentrionale). Nat. Bresc. 33:89-92.

Ficetola G.F., Thuiller W. \& Padoa-Schioppa E. 2009. From introduction to the establishment of alien species: bioclimatic differences between presence and reproduction localities in the slider turtle. Diversity Distrib. 15(1):108-116. <http://dx.doi.org/10.1111/j.1472-4642.2008.00516.x>

Firmiano E.M.S., Cardoso N.N., Santos M.A.J., Sousa B.M., Nascimento A.A. \& Pinheiro N.L. 2012. Histology and histochemistry of the oviduct of the neotropical tortoise Phrynops geoffroanus (Schweigger, 1812). J. Cytol. Histol. 3(7):1-8. <http://dx.doi.org/10.4172/2157-7099.1000164>

Flint M., Patterson-Kane J., Mills P. \& Limpus C. 2009. A Veterinarian's Guide for Sea Turtle Post Mortem Examination and Histological Investigation. The University of Queensland, Queensland. Available at <https://veterinaryscience.uq.edu.au/filething/get/4226/pm-guide-msf.pdf $>$ Access on July 2, 2019.

Fonseca F.O. 2001. Olhares Sobre o Lago Paranoá. SEMARH, Brasília. 425p.
Fox H. 1977. The urogenital system of reptiles, p.81-85. In: Gans C., Bellairs A. d'A. \& Thomas S. (Eds), Biology of Reptilia. Academic Press, New York.

Gemmell R.T. 1995. A comparative study of the corpus luteum. Reprod. Fertil. Develop. 7(3):303-312.<http://dx.doi.org/10.1071/RD9950303> <PMid:8606938>

Gibbons J.W. \& Greene J.L. 1990. Reproduction in the slider and other species of turtles. p.124-134. In: Gibbons J.W. (Ed), Life History and Ecology of the Slider Turtle. Smithsonian Institution Press, Washington DC.

Girling J.E. 2002. The reptilian oviduct: a review of structure and function and directions for future research. J. Exp. Zool. 293(2):141-170. <http:// dx.doi.org/10.1002/jez.10105><PMid:12115910>

Girling J.E., Cree A. \& Guillette Junior L.J. 1997. Oviductal structure in a viviparous New Zealand gecko, Hoplodactylus maculatus. J. Morphol. 234(1):51-68. $<$ http://dx.doi.org/10.1002/(SICI)1097-4687(199710)234:1<51::AIDJMOR5>3.0.CO;2-Q > <PMid:29852640>

Gradela A., Santiago T.O.C., Pires I.C.P., Silva A.C.S., Souza L.C., Faria M.D., Pereira Neto J. \& Milanelo L. 2017a. Sexual dimorphism in red-eared sliders (Trachemys scripta elegans) from the Wild Animal Triage Center of the Tiete Ecological Park, São Paulo, Brazil. Acta Sci. Vet. 45(1):1468. <http://dx.doi.org/10.22456/1679-9216.80442>

Gradela A., Souza V.N., Queiroz M.M., Constantino A.C., Bandeira C.G.C., Faria M.D., Milanelo L., Franzo V.S. \& Corrêa F.M. 2017b. Biometria corporal e parâmetros hematológicos de Trachemys scripta elegans e Trachemys dorbignyi (Testudines: Emydidae) criadas em cativeiro em Petrolina, Pernambuco. Pesq. Vet. Bras. 37(1):83-90. <http://dx.doi.org/10.1590/ s0100-736x2017000100014>

Guillette Junior L.J., Fox S.L. \& Palmer B.D. 1989. Oviductal morphology and egg shelling in the oviparous lizards, Crotaphytuscollaris and Eumecesobsoletus. J. Morphol. 201(2):145-159.<http://dx.doi.org/10.1002/jmor.1052010205> <PMid:29865655>

Guillette Junior L.J., Woodward A.R., You-Xiang Q., Cox M.C., Matter J.M. \& Gross T.S. 1995. Formation and regression of the Corpus Luteum of the American alligator (Alligator mississipiensis). J. Morphol. 224(1):97-110. <http://dx.doi.org/10.1002/jmor.1052240111><PMid:29865333>

Hafez E.S.E. \& Hafez B. 2004. Reprodução Animal. Manole, São Paulo. 513p.

Hamann M., Limpus C.J. \& Owens D.W. 2003.Reproductive cycles of males and females, p.135-161. In: Lutz P.L., Muzick J.A. \&Wyneken J. (Eds).The Biology of Sea Turtles. Vol.2. CRC Press, Boca Raton.

Hildebrand M. \& Goslow G. 2006. Órgãos genitais e ductos urogenitais, p.284-293. In: Ibid. (Eds), Análise da Estrutura dos Vertebrados. 2 $2^{\underline{a}}$ ed. Atheneu, São Paulo.

Iverson J.B. 1979. Reproduction and growth of the mud turtle, Kinosternon subrubrum (Reptilia, Testudinata, Kinosternidae), in Arkansas. J. Herpetol. 13(1):105-111. <http://dx.doi.org/10.2307/1563764>

Jacobson E.R. 2007. Overview of reptile biology, anatomy, and histology, p.1-2. In: Jacobson E.R. (Ed), Infections Diseases and Pathology of Reptiles: Color Atlas and Text. CRC Press Taylor and Francis Group, New York. <http:// dx.doi.org/10.1201/9781420004038.ch1>

Junqueira L.C.U. \& Carneiro J. 2008. Histologia Básica. Guanabara Koogan, Rio de Janeiro. 437p.

Kennett R. 1999. Reproduction of two species of freshwater turtle, Chelodina rugosa and Elseya dentata, from the wet-dry tropics of northern. Australia. J. Zool. 247:457-473.

Kikillus K.H., Hare K.H. \& Hartley S. 2010. Minimizing false-negatives when predicting the potential distribution of an invasive species: a bioclimatic envelope for the red-eared slider at global and regional scales. Anim. Conserv. 13(Suppl. 1):5-15. <http://dx.doi.org/10.1111/j.1469-1795.2008.00299.x>

Kondak H.C. 2012. Análise da proporção sexual e do desenvolvimento gonadal da tartaruga verde, Chelonia mydas (Linnaeus, 1758) no litoral norte e 
médio do Rio Grande do Sul. Master's dissertation, Universidade Federal do Rio Grande do Sul, Porto Alegre, RS. 41p.

Kuchling G. \& Bradshaw S.D. 1993. Ovarian cycle and egg production of the western swamp tortoise Pseudemyra umbrina (Testudines: Chelidae) in the wild and in captivity. J. Zool. Lond. 229(3):405-419. <http://dx.doi. org/10.1111/j.1469-7998.1993.tb02645.x>

Legler J.M. 1960. Natural history of the ornate box turtle, Terrapene ornate ornata Agassiz. Mus. Nat. Hist. Univ. Kans 11:527-669.

Lever C. 2003. Naturalized Amphibians and Reptiles of the World. Oxford University Press, New York.

Limpus C.J. \& Limpus D.J. 2003. Biology of the loggerhead turtle in Western South Pacific Ocean foraging areas, p.93-113. In: Bolten A.B. \& Witherington B.E. (Eds), Loggerhead Sea Turtles. Smithsonian Books, Washington.

Limpus C.J., Couper P.J. \& Read M.A. 1994. The loggerhead turtle, Caretta caretta, in Queensland: Population structure in a warm temperate feeding area. Mem. Queensl. Mus. 37:195-204.

Lutz P.L., Musick J.A. \& Wyneken J. 2003. The Biology of Sea Turtles. CRC Press, Washington.

Machado Júnior A.A.N., Sousa A.L., Santos F.C.F. \& Pereira J.G. 2006. Morfologia dos órgãos genitais femininos do muçuã (Kinosternon scorpioides). Arch. Vet. Sci. 11(2):25-29. <http://dx.doi.org/10.5380/avs.v11i2.6766>

Madekurozwa M.C. \& Kimaro W.H. 2006. A morphological and immunohistochemical study of healthy and atretic follicles in the ovary of the sexually immature ostrich (Struthiocamelus). Anat. Histol. Embryol. 35(4):253-258. <http:// dx.doi.org/10.1111/j.1439-0264.2005.00675.X > <PMid:16836590>

Malvasio A., Gomes N. \& Farias E.C. 1999. Identificação sexual através do estudo anatômico do sistema urogenital em recém-eclodidos e jovens de Trachemys dorbignyi (Duméril \& Dibron) (Reptilia, Testudines, Emydidae). Rev. Bras. Zool. 16(1):91-102. <http://dx.doi.org/10.1590/ S0101-81751999000100004>

Malvasio A., Nascimento-Rocha J.M., Santos H.D., Ataídes A.G. \& Portelinha T.C.G. 2011. Morfometria e histologia das gônadas de machos e fêmeas recém eclodidos de Podocnemis expansa e Podocnemis unifilis (Testudines, Podocnemididae). Acta Sci. Biol. Sci. 34(1):105-112.

Martinez-Silvestre A. 1997. Nota sobre lar e producciõn en condiciones naturales de la tortuga de Florida (Trachemys scripta elegans) en Masquefa (Cataluña, España). Bol. Asoc. Herpetol. Esp. 8:40-42.

Martinez-Silvestre A., Soufr-Massana J. \& Ventura-Bernardini M. 2003. Nuevas datos sobre la presencia de reptiles exóticos a silvestrados em la península iberica. Bol. Asoc. Herpetol. Esp. 14(1/2):12-14.

Mateus I.F. 2014. Patologia e Clínica de Animais Exóticos e Autóctones. Universidade de Évora, Évora. Available at <https://dspace.uevora.pt/rdpc/ bitstream/10174/13995/1/Fundamental\%20FINAL\%20IMateus\%20TT. pdf> Access on July 2, 2019.

McArthur S. 2008. Problem-solving approach to common diseases of terrestrial and semi-aquatic chelonians - Follicular stasis, p.325-329. In: McArthur S., Wilkinson R. \& Meyer J. (Eds), Medicine and Surgery of Tortoises and Turtles. Blackwell Publishing, Oxford.

Nainan H., Ping Y., Yang Y., Jinxiong L., Huijun B., Haili L., Hui Z. \& Qiusheng C. 2009. Fine structural observation on the oogenesis and vitellogenesis of the Chinese soft-shelled turtle (Pelodiseus sinensis). Zygote 18:109-120.

Nascimento M.M., Nascimento W.S., Chellappa N.T. \& Chellappa S. 2012. Biologia reprodutiva do curimatã comum, Prochilodus brevis (Characiformes: Prochilodontidae) no açude Marechal Dutra, Rio Grande do Norte, Brasil. Biota Amazonia 2(2):31-43. <http://dx.doi.org/10.18561/2179-5746/ biotaamazonia.v2n2p31-43>

Newman S.J., Brown C.J. \& Patnaik A.K. 2003. Malignant ovarian teratoma in a red-eared slider (Trachemys scripta elegans). J. Vet. Diagn. Invest. 15(1):77-81. <http://dx.doi.org/10.1177/104063870301500118> $<$ PMid:12580303>
Nogueira K. O., Rodrigues S.S., Araújo V.A. \& Neves C.A. 2011. Oviductal structure and ultrastructure of the Oviparous Gecko, Hemidactylus mabouia (Moreau De Jonne's, 1818). Anat. Rec. 294(5):883-892. <http://dx.doi. org/10.1002/ar.21375><PMid:21455958>

O’Malley B. 2005. Tortoises and turtles, p.40-56. In: Ibid. (Ed), Clinical Anatomy and Physiology of Exotic Species. Elsevier Saunders, Philadelphia.

Owens D.W. 1980. The comparative reproductive physiology of sea turtles. Am. Zool. 20(3):547-563. <http://dx.doi.org/10.1093/icb/20.3.549>

Owens D.W. \& Morris Y.A. 1985. The comparative endocrinology of sea turtles. Copeia 1985(3):723-736. <http://dx.doi.org/10.2307/1444766>

Palmer B.D. \& Guillete Junior L.T. 1988. Histology and functional morphology of the female reproductive tract of the tortoise Gopherus polyphemus. Am. J. Anat. 183(3):200-211. <http://dx.doi.org/10.1002/aja.1001830303> <PMid:3213826>

Parizzi R.C. 2006. Anatomia macroscópica e microscópica dos órgãos reprodutores femininos da Ema (Rhea amaricana). Master's dissertation, Universidade de São Paulo, São Paulo, SP. 123p.

Parizzi R.C., Miglino M.A., Maia M.O., Souza J.A., Santos J.M., Oliveira M.F. \& Santos T.C. 2007. Morfologia do ovário da ema (Rhea americana). Pesq. Vet. Bras. 27(3):89-94.<http://dx.doi.org/10.1590/S0100-736X2007000300002>

Peixoto J.V., Paula T.A.R., Balarini M.K., Matta S.L.P., Santos J.A.D., Lima C.B. \& Peixoto G.V. 2012. Morphofunctional evaluation of the testicle and the spermatogenic process of adult white-eyed parakeets (Aratinga leucophthalma Muller, 1776) during the different seasons of the year. Anat. Histol. Embryol. 41(4):248-255.<http://dx.doi.org/10.1111/j.1439-0264.2011.01128.x> $<$ PMid:22211874>

Pérez-Bermúdez E., Ruiz-Urquiola A., Lee-González I., Petric B., AlmaguerCuenca N., Sanz-Ochotorena A. \& Espinosa-López G. 2012. Ovarian follicular development in the hawksbill turtle (Cheloniidae: Eretmochelys imbricata L.). J. Morphol. 273(12):1338-1352. <http://dx.doi.org/10.1002/ jmor.20062><PMid:22821844>

Perez-Santigosa N., Diaz-Paniagua C. \& Hidalgo-Vila J. 2008. The reproductive ecology of exotic Trachemys scripta elegans in an invaded area of southern Europe. Aquatic Conserv: Mar. Freshw. Ecosyst. 18(7):1302-1310. <http:// dx.doi.org/10.1002/aqc.974>

Perkins M.J. \& Palmer B.D. 1996. Histology and functional morphology of the oviduct of an oviparous snake, Diadophis punctatus. J. Morphol. 227(1):6779.<http://dx.doi.org/10.1002/(SICI)1097-4687(199601)227:1<67::AIDJMOR5>3.0.CO;2-M><PMid:29852582>

Pessoa C.A., Rodrigues M.A., Kozu F.O., Prazeres R.F. \& Fecchio R.S. 2008. Ooforectomiavideoassistida por acesso pré-femural em targaruga-deouvido-vermelho (Trachemys scripta elegans). Pesq. Vet. Bras. 28(7):345349. <http://dx.doi.org/10.1590/S0100-736X2008000700005>

Pieau C. \& Dorizzi M. 2004. Oestrogens and temperature-dependent sex determination in reptiles: all is in the gonads. J. Endocrin. 181(3):367-377. <http://dx.doi.org/10.1677/joe.0.1810367><PMid:15171684>

Pleguezuelos J.M. 2002. Lasespeciesintroducidas de anfibios y reptiles, p. 501-532. In: Pleguezuelos J.M., Márquez R. \& Lizana M. (Eds), Atlas y Libro Rojo de los Anfibios y Reptiles de España. Dirección General de Conservación de la Naturaleza, Asociación Herpetológica Española, Madrid.

Pleguezuelos J.M. 2004. Las especies introducidas de anfibios y reptiles, p.501-532. In: Pleguezuelos J.M., Marquez R. \& Lizana M. (Eds), Atlas y Libro Rojo de los Anfibios y Reptiles de España. Direccion General de la Conservacion de la Naturaleza, Asociacion Herpetologica Espanola, Madrid.

Pupins M. 2007. First report on recording of the invasive species Trachemys scripta elegans, a potential competitor of Emys orbicularis in Latvia. Acta Univ. Lat. 723:37-46. Available at <https://www.freewebs.com/ trachemysadoption/articles/Pupins.pdf> Access on July 2, 2019.

Querol M.V.M., Querol E. \& Gomes N.N.A. 2002. Fator de condição gonadal, índice hepatossomático e recrutamento como indicadores do período de reprodução de Loricariichthys platymetopon (Osteichthyes, Loricariidae), 
Bacia do rio Uruguai médio, Sul do Brasil. Iheringia, Sér. Zool. 92(3):79-84. <http://dx.doi.org/10.1590/S0073-47212002000300008>

Radder R. \& Shine R. 2007. Germinal bed condition in a polyautochronic singleclutched lizard, Bassianaduperreyi (Scincidae). Amph Rept. 28(1):159-162. <http://dx.doi.org/10.1163/156853807779799018>

Ramo C. 1982. Biología del galápago Podocnemis vogli (MULLER, 1935) enhatoel Frío, llanos de Apure (Venezuela). Doñana Acta Vertebrata 9(3):1-61.

Ramsay N.F., Ng P.K.A., O'Riordan R.M. \& Chou L.M. 2007.The red-eared slider (Trachemys scripta elegans) in Asia: a review, p. 161-174. In: Gherardi F. (Eds), Biological Invaders in Inland Waters: Profiles, Distribution, and Threats. Springer Publishing, Dordrecht. <http://dx.doi.org/10.1007/9781-4020-6029-8_8>

Ricciardi A. 2007. Are modern biological invasions an unprecedented form of global change? Conserv. Biol. 21(2):329-336. <http://dx.doi. org/10.1111/j.1523-1739.2006.00615.x><PMid:17391183>

Rosa L. 2005. Biologia reprodutiva da tartaruga marinha Chelonia mydas no litoral paranaense. Graduation monograph, Universidade Federal do Paraná, Paraná, PR. 30p.

Rosa L. 2009. Estudo da biologia reprodutiva na fase juvenil da Tartarugaverde (Cheloniamydas) no litoral do Estado do Paraná. Master's dissertation, Programa de Pós-graduação em Sistemas Costeiros e Oceânicos, Centro de Estudos do Mar, Universidade Federal do Paraná, Pontal do Paraná. 72p.

Rosanova P., Romano M., Marciano R., Anteo C. \& Limatola E. 2002. Vitellogenin precursors in the liver of the lizard Podarcissicula. Mol. Reprod. Dev. 63(3):349-354. <http://dx.doi.org/10.1002/mrd.90019><PMid:12237951>

Rossi S., Lovato E. \& Hofling J.C. 2006. Aspectos biológicos da tartarugade-orelhas-vermelhas, Trachemys scripta elegans (Reptilia, Testudines, Emydidae) em cativeiro. Bioikos 20(1):33-40.

Sever D.M., Ryan T.J., Morris T., Patton D. \& Swafford S. 2000. Ultrastructure of the reproductive system of the black swamp snake (Semina trixpygaea). II. Annual Oviducal Cycle. J. Morphol. 245(2):146-160. <http://dx.doi. org/10.1002/1097-4687(200008)245:2<146::AID-JMOR5>3.0.CO;2-F> $<$ PMid:10906748>

Silva G.F.N., Freire V.T.O., Matos W.C.G., Pereira Neto J., Seyfert C.E., Andrade N.S. \& Faria M.D. 2011. Dimensions, mass and volume of the liver of turtles (Trachemys scripta elegans WIED, 1839). J. Morphol. Sci. 28(4):235-239.

Silva W.F., Lima R.L., Pinheiro J.N., Brito E.S. \& Ferraz R.H.S. 2017. Morfologia de órgãos genitais femininos de quelônio semi-aquático Mesoclemmys vanderhaegei. Pesq. Vet. Bras. 37(9):1015-1024. <http://dx.doi.org/10.1590/ s0100-736x2017000900018>

Souza A.F., Costa S.G.A.L., Morais D.B. \& Molina W.F. 2014. Diversidade morfológica dos órgãos copulatórios dos vertebrados: uma revisão. Biota Amazônia 4(4):114-122. <http://dx.doi.org/10.18561/2179-5746/ biotaamazonia.v4n4p115-123>

Storer T.I., Usinger R.L., Stebbins R.C. \& Nybakken J.W. 2000. Zoologia Geral. Companhia Editora Nacional, São Paulo, p.642-654.

Strayer D.L., Eviner E.V., Jeschke J.M. \& Pace M.L. 2006. Understanding the long-term effects of species invasions. Trends Ecol. Evol. 6(11):45-51. <http://dx.doi.org/10.1016/j.tree.2006.07.007><PMid:16859805>
Taniguchi M., Lovich J.E., Mine K., Ueno S. \& Kamezaki N. 2017. Unusual population attributes of invasive red-eared slider turtles (Trachemys scripta elegans) in Japan: do they have a performance advantage? Aquat. Invasions 12(1):97-108. <http://dx.doi.org/10.3391/ai.2017.12.1.10>

TCF 2002. A global action plan for conservation of tortoises and freshwater turtles. Conservation International \& Chelonian Research Foundation, Turtle Conservation Fund, Washington, D.C.

Teillac-Deschamps P., Delmas V., Lorrillière R., Servais V., Cadi A. \& PrévotJulliard A.-C. 2008. Case study 12: red-eared slider turtles Trachemys scripta elegans introduced to French urban wetlands: an integrated research and conservation program. In: Mitchell J.C., R.E. Jung Brown \& Bartholomew B. (Eds), Urban Herpetology. Herpetological Conservation 3. Society for the Study of Amphibians and Reptiles, Salt Lake City. Available at <http:// www2.mnhn.fr/cersp/IMG/pdf/Tiellac_al-HerpetologicalConservation-2008. pdf> Access on July 2, 2019.

Telecky T.M. 2001. United States import and export of live turtles and tortoises. TTN 4:8-13.

Tucker J.K. \& Janzen F.J. 1998. Order of oviposition and egg size in the redeared slider turtle (Trachemys scripta elegans). Can. J. Zool. 76(2):377-380. <http://dx.doi.org/10.1139/z97-198>

Tucker J.K. \& Moll D. 1997. Growth, reproduction, and survivorship in the red-eared turtle, Trachemys scripta elegans, in Illinois, with conservation implications. Chelonian Conserv. Biol. 2:352-357.

Tucker J.K., Paukstis G.L. \& Janzen F.J. 1998. Annual and local variation in reproduction in the red-eared slider, Trachemys scripta elegans. J. Herpetol. 32(4):515-526. <http://dx.doi.org/10.2307/1565205>

Velasquez J.D.L.O. \& Vogt R.C. 2011. Ciclo ovárico y jerarquía folicular de Peltocephalus dumerilianus (Testudines: Podocnemididae). Acta Amaz. 41(2):243-250. <http://dx.doi.org/10.1590/S0044-59672011000200008>

Vieira C.S. \& Costa E.M.E. 2006. Análise da estrutura populacional de Trachemys scripta elegans (Chelonia) no Parque Ecológico Olhos D'água - Brasília - DF. Univ. Ciênc. Saúde 4(1/2):1-8.

Webb R.G. 1961. Observations on life histories of turtles (genus Pseudemys and Graptemys) in Lake Texoma, Oklahoma. Am. Midl. Nat. 65(10):193214. <http://dx.doi.org/10.2307/2423013>

Wibbels T., Owens D.W., Limpus C.J., Reed P.C. \& Amoss-Junior M.S. 1990. Seasonal changes in serum gonadal steroids associated with migration, mating and nesting in the loggerhead sea turtle (Caretta caretta). Gen. Comp. Endocrinol. 79(1):154-164. <http://dx.doi.org/10.1016/00166480(90)90099-8><PMid:2354777>

Wyneken J. 2001. The Anatomy of Sea Turtles. NOAA, Miami, FL, p.180.

Wyneken J., Epperly S.P., Growder L.B., Vaughan J. \& Esper K.B. 2007. Determining sex in posthatchling loggerhead sea turtles using multiple gonadal and accessory duct characteristics. Herpetologica 63(1):19-30. <http://dx.doi.org/10.1655/0018-0831(2007)63[19:DSIPLS]2.0.CO;2>

Zeyl J.N., Love O.P. \& Higgs D.M. 2013. Evaluating gonadosomatic index as an estimator of reproductive condition in the invasive round goby, Neogobius melanostomus. J. Great Lakes Res. <http://dx.doi.org/10.1016/j. jglr.2013.12.004> 